\title{
DIE DIALEKTIEK IN DIE WAARDES VAN DIE 1996 GRONDWET
}

\author{
Jan Swanepoel* $^{*}$
}

\section{INHOUDSOPGAWE}

$1 \quad$ Inleiding

2 Enkele perspektiewe op die 1996 Grondwet

3 Waardeterme en waardes in die 1996 Grondwet

4 Perspektiewe op die Suid-Afrikaanse demokrasie

$5 \quad$ Die dialektiek tussen artikels 1(a) en 7(1)

6 Die “oop plek": regstaat of sosiale demokrasie?

$7 \quad$ Die ruimere filosofiese kader: mens-, samelewing- en staatsbeskouing

8 Intertekstuele eggo's

$9 \quad$ Tekstuele argumente ten gunste daarvan dat artikel 7(1) die hooflyn verteenwoordig

10 Tekstuele argumente ten gunste daarvan dat artikel 1(a) die hooflyn verteenwoordig

11 Konklusie

\section{$1 \quad$ Inleiding}

Die oogmerk met hierdie artikel is om ondersoek in te stel na die vernaamste waardes in Die Grondwet van die Republiek van Suid-Afrika 108 van 1996 en om na te gaan of hierdie waardes koherensie vertoon. Die kernvraag is of die 1996 Grondwet waardegewys uit een mond of uit meerdere monde praat, of dit een- of meerstemmig is? 'n Vraagstuk wat hiermee saamhang is hoe die soort staat wat die 1996 Grondwet daarstel, getipeer moet word. Moet dit as 'n regstaat in die liberale tradisie beskou word of moet dit eerder gesien word as 'n sosiale demokrasie?

In hierdie artikel sal aangetoon word dat

- die 1996 Grondwet onpresies is in die gebruik van waardeterme

\footnotetext{
${ }^{*}$ Fakulteit Regte, Potchefstroom.
} 
- daar 'n bepaalde dialektiek of spanningsverhouding in die waardes van die 1996 Grondwet aanwysbaar is, en dat

- die tipering van watter soort staat Suid-Afrika onder die 1996 Grondwet is, afhang van die antwoord op die vraag aan watter van die twee pole in hierdie dialektiek van waardes daar voorrang verleen word.

\section{Enkele perspektiewe op die 1996 Grondwet}

\subsection{Die 1996 Grondwet as kompromisdokument}

By die bespreking van hierdie vraagstukke moet daarmee rekening gehou word dat die 1996 Grondwet ongetwyfeld die produk van politieke en ideologiese kompromie is. Om met Du Plessis ${ }^{1}$ te praat: "The text reverberates ... bargaining and compromise." As die opvolger van die Grondwet van die Republiek van Suid-Afrika 200 van 1993, is dit erfgenaam van bepaalde kompromieë wat in die totstandkoming van die 1993 Grondwet aangegaan is. By die opstel van die 1996 Grondwet het die Grondwetlike Vergadering geen vrypas gehad om na goeddunke op te tree nie. Die 1996 Grondwet moes voldoen aan die Grondwetlike Beginsels wat in Bylae 4 van die 1993 Grondwet neergelê is. Die vier en dertig beginsels wat in hierdie bylae vervat is, het die breë raamwerk neergelê wat vir die finale Grondwet sou geld. Wat meer is, daar is in artikel 71 van die 1993 Grondwet voorsiening daarvoor gemaak dat die Konstitusionele Hof moes sertifiseer dat die finale Grondwet inderdaad aan hierdie beginsels voldoen, iets wat hoogs uitsonderlik is.

Daar moet in aanmerking geneem word dat grondwette dikwels tot stand kom wanneer daar 'n nuwe begin gemaak word. As sodanig volg dit meermale op 'n tydperk van spanning en stryd, selfs van krisis. ${ }^{2}$ So verwoord die 1996 Grondwet enersyds bepaalde ideale wat vir die toekoms gekoester word, maar andersyds kan die merktekens van die

11996 Stell LR 3.

2 Vgl De Waal 1995 SAJHR 2: " [...] constitutions are often adopted in reaction to historical struggles and peculiar historical events." 
verlede duidelik daarin gesien word. Die ideale wat nagestreef word, is dikwels die teenkant van daardie dinge uit die verlede wat voortaan vermy moet word.

Dat daar 'n dialektiese verhouding tussen bepaalde waardes in die 1996 Grondwet voorkom, hoef 'n mens nie heeltemal te verras nie. Afgesien daarvan dat hierdie Grondwet die produk van politieke kompromie is, ${ }^{3}$ moet in gedagte gehou word dat dit 'n algemene verskynsel is dat grondwette (en in besonder die gesaghebbende waardeuitsprake wat in handveste van regte voorkom) wyd geformuleer word. Du Plessis ${ }^{4}$ merk in hierdie verband op:

Characteristically, they are expressed as general norms, as broadly as possible, and formulations which are too detailed are avoided as far as possible. ${ }^{5}$ This results in, amongst others, in flexibility and adaptability.

Die dialektiek van waardes en die onduidelikhede wat daaruit voortspruit is op 'n dieper vlak aanduidend van die diversiteit van waardes en belange wat in 'n moderne staat met mekaar geharmoniseer en versoen moet word. ${ }^{6}$ Dit geld nog des te meer in die bepaalde sosio-politieke konteks waarin die grondwetlike transformasie in Suid-Afrika plaasgevind het.

\subsection{Die normatiwiteit van grondwette}

Grondwette word tereg as waarde-georiënteerde dokumente beskryf. ${ }^{7}$ Die 1996 Grondwet vertoon 'n dubbele normatiwiteit. Dit is enersyds normatief in die sin dat bepaalde waardes (wat elk 'n geskiedenis het) daarin vervat is. As 'n historiese dokument

3 Botha 1994 SAPR/PL 240.

41996 Stell LR 3, met verwysing na Corder, Kahanovitz, Murphy, Murray, O’Regan, Sarkin, Smith \& Steytler A Charter for Social Justice: a Contribution to the South African Bill of Rights Debate (1992) 17-18.

5 Dit geld ongetwyfeld van die 1996 Grondwet, soos blyk uit die feit dat daar vermy word om in die Grondwet self oor etlike kontensieuse aangeleenthede (soos die grondwetlikheid al dan nie van die doodstraf en van aborsie) uitsluitsel te gee.

6 Kyk Botha 1994 SAPR/PL 240.

$7 \quad$ Erasmus en De Waal 1997 Stell LR 31. 
is dit die draer van sekere waardes wat histories ontwikkel het. In hierdie sin kan dit 'n "repository of values" genoem word. Daar kan aangetoon word hoe bepaalde waardes (byvoorbeeld humanistiese, liberalistiese of sosialistiese waardes) daarin vergestalt is.

Die 1996 Grondwet is egter ook normatief in 'n ander belangriker sin. Die waardes wat daarin beliggaam is, dien as maatstaf of norm waaraan ander wette, handelinge en verskynsels getoets word. As sodanig het die Grondwet 'n bepaalde status. Daar kan sonder vrees vir teenspraak gesê word dat 'n grondwet as die belangrikste regs- en staatkundige dokument beskou word in lande waar 'n grondwet tot Grundnorm verhef is. ${ }^{8}$ Suid-Afrika val in hierdie kategorie. Dit blyk onder meer uit die Aanhef tot die 1996 Grondwet waar daar eksplisiet na hierdie Grondwet verwys word as "die hoogste reg van die Republiek". ${ }^{9}$ Artikel 2 bevestig hierdie toedrag van sake en stel dit duidelik dat enige regsvoorskrif of optrede wat daarmee onbestaanbaar is, ongeldig is.

\section{$2.3 \quad$ Koherensie}

Grondwette (en die waardes daarin vervat) behoort idealiter koherensie te vertoon. ${ }^{10}$ Dit is so vanweë die normatiewe aard daarvan en na aanleiding van die funksie wat dit in die breë samelewing vervul, nie net op juridiese gebied nie, maar ook op staatkundige, sosiale en ekonomiese terrein. Dit is daarom verkieslik dat grondwette helder, maar tegnies presies geformuleer moet word. Dit geld nie net die taal en styl daarvan nie, maar ook die struktuur daarvan:

The overall structure or "system" of the text is vital too. The text must be capable of being read as a coherent whole. Its various components must "fit" - and do so "sensibly". ${ }^{11}$

8 Vir Suid-Afrika het hierdie waterskeiding reeds in 1994 aangebreek toe afstand gedoen is van 'n bedeling waar parlementêre soewereiniteit die deurslag gegee het en oorgegaan is tot 'n bedeling waarin die Grondwet die hoogste gesag is.

9 Die ooreenstemmende artikel in die 1993 Grondwet is a 4.

10 Dit gebeur dikwels dat die gewensde koherensie ontbreek. Botha 1994 SAPR/PL 240 verwys byvoorbeeld na die 1993 Grondwet as 'n "site of conflict between different values".

11 Du Plessis 1996 Stell LR 4. 
Sekerheid met betrekking tot die norm werk regsekerheid in die hand. As die norma nie 'n hoek van negentig grade maak nie, is dit hoogs onwaarskynlik dat die mure van die spreekwoordelike bouwerk van 'n nuwe grondwetlike bedeling reghoekig opgetrek sal word.

Terwyl grondwette duidelikheid en regsekerheid in die hand moet werk, moet hierdie kenmerke nie verwar word met starheid en 'n gebrek aan dinamiek nie. Grondwette moet nie net regsekerheid in die hand werk nie, maar moet ook die nodige soepelheid en aanpasbaarheid vertoon.

\section{$2.4 \quad$ Uitleg}

As sodanig verg grondwette 'n bepaalde soort uitleg, wat aanmerklik verskil van die tradisionele benadering wat Suid-Afrikaanse howe in die bedeling voor 1994 gevolg het. Daar kan nie langer volstaan word met die argaïese en gediskrediteerde hermeneutiese teorieë wat daarop ingestel was om die wetgewersbedoeling aan die hand van die duidelike taal van die woorde in 'n teks vas te stel nie. ${ }^{12}$ 'n Grondwet soos die 1996 Grondwet vereis 'n normatiewe uitleg. Die uitlegbenadering moet minstens deeglik rekening hou met en kennis neem van die waardes wat in die 1996 teks vervat is. Dit hou in dat regters 'n bereidheid sal moet toon om die terrein van beleidsaangeleenthede te betree. Dit is besonder kragtig geformuleer deur Froneman $r$ in 'n onlangse voordrag voor die Conference on Legal Theory by die RAU in September 1997. Ietwat versigtiger geformuleer was die standpunt van regter Chaskalson, President van die Konstitusionele Hof, wat by dieselfde geleentheid grondwetlike uitleg vergelyk het met 'n deurvaart tussen die bedrieglike Scylla en Charybdis. Hy het instemmend aansluiting gevind by die dictum van Kentridge wn $\mathrm{r}$ in $S$ v Zuma. ${ }^{13}$ Hiervolgens moet daar deeglik rekening gehou word met die waardes van die Grondwet, maar moet daar nogtans deurgaans in gedagte

12 Du Plessis Jurisprudence of Interpretation 6 skryf in hierdie verband: "... the supreme constitution always trumps the 'intention of the legislature' -- no matter how clear and manifest this intention appears to be: ..." 
gehou word dat die Grondwet "a written instrument" is wat geïnterpreteer word. Alhoewel waardes hiervolgens belangrik is en daar deeglik daarmee rekening gehou moet word, kan woorde nie maar beteken net wat die interpreteerder dit wil laat beteken nie.

\section{$3 \quad$ Waardeterme en waardes in die 1996 Grondwet}

\subsection{Waarde-uitsprake}

Waarde-uitsprake kom prominent voor in die Aanhef, in artikel 1(a) en in die Handves van Regte van die 1996 Grondwet. $^{14}$

Belangrike aanduidings van die soort bedeling wat die Grondwet in die vooruitsig stel, kan reeds uit die Aanhef en uit die sogenaamde stigtingsartikel ${ }^{15}$ afgelees word. Die Handves van Regte neem egter in hierdie verband 'n sentrale plek in. In teenstelling tot die retoriek wat dikwels 'n Aanhef kenmerk, ${ }^{16}$ is 'n Handves die dokument wat die waardes as 't ware moet operasionaliseer. ${ }^{17}$ Omdat die afdwingbaarheid van regte hier in die spel kom, is noukeurige juridies-korrekte formulering van die grootste belang. Die Handves van Regte in die 1996 Grondwet neem kennelik 'n kardinale plek daarin in. Dit blyk uit die feit dat dit van toepassing is op die totale reg en die wetgewende, die uitvoerende en die regsprekende gesag en alle staatsorgane bind. ${ }^{18}$

\subsection{Waardeterme in die 1996 Grondwet}

Daar kom 'n wye verskeidenheid waardeterme in die 1996 Grondwet voor. Daar word vervolgens, teen die agtergrond van die Willem van Ockham se stelreël entia non

$13 S v$ Zuma and Others 1995(4) BCLR 401 (SA) op 412F.

14 Hierdie opmerking sluit nie uit dat waarde-uitsprake ook elders in die Grondwet aangetref word nie.

15 A 1.

16 Die narede van die 1993 Grondwet, waarin daar voorsiening gemaak word vir die verlening van amnestie aan persone wat hulle met 'n politieke oogmerk aan growwe menseregteskendings skuldig gemaak het, is besonder sterk retories geformuleer. Dit is egter uitsonderlik dat 'n grondwet 'n narede bevat.

17 Du Plessis 1996 Stell LR 6.

18 A 8(1). 
multiplicanda praeter necessitatem, ${ }^{19}$ ondersoek na hierdie waardeterme ingestel. Daar moet in hierdie verband onderskei word tussen die terme wat breedweg op waardes dui (byvoorbeeld "waarde", "beginsel", "grondslag" en dergelike meer) en dit waarvoor die waarde staan. Na die eerste hiervan sal verwys word as waardeterme, na die tweede as die waardes.

\subsection{Excursus: waardeterme in tegniese sin}

Die 1996 Grondwet gebruik 'n groot aantal waardeterme. Daar is sprake van "waardes", "beginsels" en "grondslae". Ook "basisse" en "doelwitte" of "oogmerke" kan na aanleiding van woorde soos "baseer" en "ten einde" uit die teks gekonstrueer word.

Daar moet opgemerk word dat bogenoemde waardeterme in filosofiese sin nie dieselfde strekking het nie. Voordat daar ingegaan word op die betekenis van hierdie terme soos wat dit in die 1996 Grondwet gebruik word, is dit goed om na te gaan watter tegniese betekenis daar gewoonlik aan hierdie terme geheg word.

'n Beginsel dui op 'n vertrekpunt, dit wil sê erens waar daar begin word. As 'n mens met 'n beginsel vertroud is, dan kan jy ander dinge logies daaruit aflei. Filosofies gesproke het "beginsels" 'n rasionalistiese en logisistiese kleur. ${ }^{20}$ Waar daar sprake van "beginsels" is, is "sisteem" of 'n groter samehangende verband waaraan hierdie beginsel(s) ten grondslag lê, gewoonlik nie ver weg nie. Vandaar dan ook dat

"beginsels" (in teenstelling tot byvoorbeeld die negentiende eeu) nie soveel gewildheid in 'n postmodernistiese tyd soos die laat twintigste eeu geniet nie.

Veel gewilder in ons eie tyd is die vermelding en vooropstelling van "waardes". Hierdie "waardes" het die funksie om mense saam te bind of te verenig. Dit is iets wat rigting gee

19 Van Eikema Hommes Elementaire Grondbegrippen 443; Van Haersolte Rawls 212. Die Afrikaanse vertaling van die stelreël lui: "Dinge moet nie vermenigvuldig word verder as wat noodsaaklik is nie".

20 Venter 1994 Orientation 262. 
aan mense of instansies in hul daaglikse optrede. Dikwels word waardes voorgehou as iets wat nagestreef word of as iets wat 'n mens se optrede rig.

Dit is nie moeilik om in te sien waarom daar op staatkundige en grondwetlike terrein dikwels van waardes gepraat word nie. In Suid-Afrika met sy heterogene bevolking en sy geskiedenis van skeiding word "waardes" meermale beskou as iets wat mense kan verenig. 'n Gedeelde respek vir bepaalde waardes sou mense kon saamsnoer. ${ }^{21}$ In hierdie sin kom waardes baie naby aan "ideale", daardie moeilik bereikbare dinge wat deur mense of groepe nagestreef word, en wat ten spyte van die beste bedoelings nie altyd verwesenlik word nie. Die feit dat dit nie verwesenlik word nie, ontneem hierdie ideale egter nie sonder meer hul krag nie, aangesien dit 'n invloed kan hê op die staatsgedragslyn.

Dit is goed om in gedagte te hou dat die term "waarde" meermale 'n ekonomiese konnotasie het. Die belang daarvan vir hierdie bespreking is dat waardes eers sinvol is wanneer die metingstandaard bekend is. Dit impliseer die bestaan van vergelykende standaard of norm van waardebepaling. Anders gestel, 'n waardestelsel verg die aanwending van norme; daarsonder is dit onprakties. 'n Normatiewe benadering hou in dat konkrete optrede gemeet word aan bepaalde maatstawwe. Van hierdie norme gaan 'n appèl uit. Dit plaas op persone 'n bepaalde verantwoordelikheid wat hulle moet vervul.

Dit wat die staatsvolk saambind, kan ook as doelwitte of mikpunte geformuleer word. Doelwitte is iets engers en meer spesifiek as waardes. Doelwitte word geformuleer met die oog daarop om in die praktyk verwerklik te word. Juis daarom word die verwerkliking daarvan gewoonlik aan spesifieke tydskale gekoppel. Die filosofiese kader hiervan is die pragmatisme, wat in die breë kader van die irrasionalisme tuishoort. $^{22}$ In 'n wêreld waarin die mens nie oor al die antwoorde beskik nie, maar nogtans met sy beperkte insig van dag tot dag belangrike beslissings moet maak, word

\footnotetext{
${ }^{21}$ Kyk Mahomed $\mathrm{r}$ se opmerkings in S v Makwanyane 19953 SA 391 (KH) par [262] oor die samebindende funksie van waardes in grondwette.

22 Venter 1994 Orientation 271.
} 
daar graag met 'n doelwitbenadering gewerk. Eerder as om te verval in eindelose besinning wat uiteindelik geen finale antwoorde oplewer nie; word die mens gestel voor haalbare en kontroleerbare doelwitte. Juis daarom skep dit die indruk van 'n praktiese benadering. Doelwitgeoriënteerdheid word hoog geag in 'n samelewing wat ingestel is op die bereiking van duidelik geformuleerde uitkomste. Dit floreer in samelewings wat sterk bestuursmatig ingestel is.

\subsection{Terminologiese probleem}

Na hierdie algemene oorsig kan nou oorgegaan word tot 'n oorsig oor hoe waardeterme in die 1996 Grondwet gebruik word. Slegs die vernaamste terminologiese probleme sal kortliks toegelig word.

- Eerstens is dit opvallend dat daar meermale van "waardes en beginsels" en in een asem gepraat word.

In sekere kontekste word waardes en beginsels skynbaar as sinonieme gebruik. 'n Goeie voorbeeld hiervan is in Hoofstuk 10 wat handel oor openbare administrasie. Die subopskrif van Hoofstuk 10 lees: "Basiese waardes en beginsels wat openbare administrasie beheers". Hierdie opskrif wil dit laat voorkom of waardes en beginsels gelykgeskakel word. Hierdie indruk word versterk deur artikel 195(3) wat stel dat nasionale wetgewing "die waardes en beginsels in subartikel (1) moet bevorder. Dieselfde geld vir artikel 196(4).

- In ander kontekste wil dit egter voorkom of waardes en beginsels nie uitruilbaar is nie. Die formulering in artikel 195(1) wat direk op die subopskrif in Hoofstuk 10 volg, lui soos volg:

Openbare administrasie word beheers deur die demokratiese waardes en beginsels wat in die Grondwet verskans is, met inbegrip van die volgende beginsels: [...] 
Hierna word 'n lang lys beginsels in subartikels (a) tot (i) gelys, te wete 'n hoë standaard van beroepsetiek, die wyse van hulpbronaanwending, ontwikkelingsgerigtheid, onpartydigheid en dies meer, 'n ingesteldheid op menslike behoeftes en deelname aan beleidsvorming, verantwoordingspligtigheid, deursigtigheid en inligtingsvoorsiening, bestuur asook verteenwoordigendheid.

Hieruit wil dit voorkom of "beginsels", soos wat dit in artikel 195 gebruik word, prakties gerigte voorskrifte is en dat dit in die 1996 Grondwet op iets enger as waardes dui.

Dieselfde kan gesê word van die "bepalende beginsels" wat in artikel 181, die inleidingsartikel van Hoofstuk 9, vermeld word. Hierdie artikel het betrekking op beginsels met betrekking tot staatsinstellings ter ondersteuning van 'n grondwetlike demokrasie. Dit sluit onder meer die volgende beginsels in: onafhanklikheid, onpartydigheid, waardigheid, doeltreffendheid en verantwoordingspligtigheid.

Uit hierdie oorsig wil dit voorkom of "beginsels", soos wat die 1996 Grondwet dit gebruik, op 'n laer, praktiese vlak funksioneer, terwyl die term "waardes" veral gereserveer word vir hoër dinge wat of nagestreef word of wat vir dinge as grondslag dien.

- "Waarde" en "grondslag" word soms uitruilbaar gebruik. Terwyl die Grondwet meermale na menswaardigheid, gelykheid en vryheid as waardes verwys, blyk dit onder meer uit die formulering van artikels 36(1) en 39(1)(a) dat hierdie waardes die rol van grondslae van 'n oop en demokratiese samelewing vervul.

- Daar word by geleentheid melding gemaak van "die gees, strekking en oogmerke" van die Grondwet. Hierdie kluster waardeterme kom in artikel 39(2) voor:

By die uitleg van enige wetgewing, en by die ontwikkeling van die gemene reg of gewoontereg, moet elke hof, tribunaal of forum die gees, strekking en oogmerke van die Handves van Regte bevorder. 
Alhoewel 'n verwysing na "gees" iets metafisies impliseer, dui hierdie formulering waarskynlik bloot daarop dat die Handves van Regte as norm dien, wanneer wetgewing uitgelê of wanneer die gemene reg of gewoontereg ontwikkel word.

Teen die agtergrond van hierdie uiteensetting kan aangevoer word dat:

- Die terme waarde en beginsel word meermale gebruik sonder om voldoende daartussen te onderskei. Die verhouding tussen hierdie begrippe word ook nêrens eksplisiet verduidelik nie.

- Die term waarde word dikwels soos grondslag gebruik.

Die veelheid van terme asook die feit dat dit nie eenduidig gebruik word nie dui daarop dat daar in die konteks van die 1996 Grondwet nie streng daartussen onderskei kan word of aangetoon kan word wat die onderlinge verhouding daartussen is nie. Dit wil voorkom of hierdie terme enersyds losweg dui op daardie dinge wat ten grondslag lê aan die bedeling wat deur die Grondwet tot stand gebring word. Andersyds wil dit wys op daardie hoëre dinge wat aan hierdie nuwe bedeling rigting gee, dit wil sê daardie dinge waarna daar gestreef word of waarop hierdie bedeling gemik is.

- Dit sou wenslik wees dat waardeterme met groter presisie gebruik word, veral in die lig daarvan dat sodanige begrippe waarskynlik 'n belangrike rol sal speel by die uitleg van die 1996 Grondwet, net soos wat die geval met die 1993 Grondwet was. ${ }^{23}$ Daar moet opgemerk word dat hierdie onpresiesheid nie tot die 1996 Grondwet self beperk is nie, maar dat dit ook gereeld voorkom in literatuur wat oor die Grondwet geskryf word.

\subsection{Substantiewe probleme}

\subsubsection{Van waardeterme na waardes}

23 Vgl Froneman r se opmerking in Qozeleni v Minister of Law and Order 19943 SA 625 (OK) met betrekking tot die belangrikheid van grondwetlike beginsels en waardes in 'n bedeling waar die 
Blote terminolgiese onduidelikhede kan moontlik as taalkundige vitterigheid afgemaak word. Dit is egter goed moontlik dat die terminologiese eienaardighede substantiewe probleme mag versluier. Daarom word die terminologiese probleem en die substantiewe probleem vervolgens in samehang bespreek, en wel aan die hand van drie sleutelpassasies in die Grondwet, te wete die Aanhef, die stigtingsbepaling (artikel 1(a)) en die inleidingsartikel tot die Handves van Regte (artikel 7(1)).

By hierdie bespreking moet in gedagte gehou word dat etlike van hierdie waardes (soos menswaardigheid, gelykheid en vryheid) baie ruim is. Daar is reeds in die loop van die geskiedenis in verskillende tydvakke bepaalde inhoud daaraan gegee. Sodanige inhoudgewing is nie iets staties en afgehandeld nie. Die proses duur vandag steeds voort. Dit impliseer dat betekenis iets dinamies is en dat tekste (en dus ook die 1996 Grondwet) nie selfgenoegsaam is nie. In die invulling en toesegging van betekenis speel die leser se eie agtergrond en historiese gesitueerdheid 'n belangrike rol. Daar kan gevolglik verwag word dat lesers iets van hul Suid-Afrikaanse agtergrond gaan inbring in hul interpretasie van waardes soos menswaardigheid, gelykheid en vryheid. ${ }^{24}$

Die feit dat die Handves van Regte in die 1996 Grondwet so oop en ruim geformuleer is en dat so veel "Solomonic solutions" daarin aangewys kan word, ${ }^{25}$ bied voldoende geleentheid vir 'n interpretasie van die Grondwet deur die howe wat tyd- en kontekssensitief is. Verder moet in gedagte gehou word dat 'n onderskrywing van 'n sensitiwiteit vir die Suid-Afrikaanse konteks dit hoegenaamd nie uitsluit nie dat die Volkereg ook sy invloed kenbaar sal maak in die manier waarop die Handves van Regte uitgelê word, ${ }^{26}$ soos blyk uit die verpligting wat ingevolge artikel 39(1)(b) aan howe, tribunale en fora opgelê word.

Grondwet die hoogste reg is waarteen alle ander reg getoets moet word om vas te stel of dit inderdaad in ooreenstemming met die Grondwet is.

25 Kyk Michelman Constitutional Authorship 28. 


\subsubsection{Aanhef}

In die Aanhef word gestel dat die 1996 Grondwet as hoogste reg van die Republiek aangeneem word om sekere doelstellings te bereik. Dat dit hier om doelstellings gaan, blyk uit die gebruik van die woord "ten einde". Die Grondwet is teleologies daarop gerig om die volgende doelwitte of oogmerke te bereik, naamlik om:

- die verdeeldheid van die verlede te heel

en 'n samelewing gegrond op demokratiese waardes, maatskaplike geregtigheid en basiese menseregte te skep

- die grondslag te lê vir 'n oop en demokratiese samelewing waarin regering gegrondves is op die wil van die bevolking en elke burger gelyk deur die reg beskerm word

- die lewensgehalte van alle burgers te verhoog en die potensiaal van alle burgers te ontsluit

- 'n verenigde en demokratiese samelewing te bou wat sy regmatige plek as 'n soewereine staat in die gemeenskap van nasies inneem.

Hieruit moet afgelei word dat die 1996 Grondwet as hoogste reg aangeneem word om die grondslag te lê vir 'n oop en demokratiese samelewing. Hierdie samelewing (wat as oop en demokraties getipeer word) is op sy beurt gegrond op (of: het as grondslae) demokratiese waardes, maatskaplike geregtigheid en basiese menseregte.

\subsubsection{Artikel 1(a)}

In hierdie stigtingsartikel (wat uiteraard 'n belangrike artikel is) word gestel dat SuidAfrika een, soewereine, demokratiese staat is wat op ' $n$ aantal waardes gegrond is, te wete:

26 Vir 'n bespreking van die werking van sogenaamde "international human rights" ooreenkomstig die 
- menswaardigheid

die bereiking van gelykheid

die uitbou van menseregte en vryhede ${ }^{27}$

- $\quad$ nie-rassigheid en nie-seksisme ${ }^{28}$

- die oppergesag van die grondwet en die heerskappy van die reg ${ }^{29}$

- $\quad$ algemene stemreg vir volwassenes

'n nasionale gemeenskaplike kieserslys

gereelde verkiesings

'n veelparty-stelsel van demokratiese regering

wat ten doel het om verantwoordingspligtigheid, 'n responsiewe ingesteldheid en openheid te verseker. ${ }^{30}$

Dit is ooglopend dat betreklik uiteenlopende dinge in artikel 1 saamgegroepeer is onder die sambreelterm "waardes". Verder is dit opmerklik dat waardes en grondslae in artikel 1 baie nou met mekaar saamhang. Bepaalde waardes dien as grondslae vir die Republiek van Suid-Afrika.

\subsubsection{Artikel 7(1)}

Artikel 7(1), die inleidingsartikel van die Handves van Regte, herinner gedeeltelik aan die Aanhef en aan artikel 1(a). Waar die Aanhef die Grondwet voorstel as die grondslag van 'n demokratiese en oop samelewing, word die Handves van Regte (Hoofstuk 2) voorgehou as die "hoeksteen" (die grondslag van die grondslag?) van die demokrasie in Suid-Afrika. Hierdie Handves verskans die regte van alle mense in Suid-Afrika en bevestig die "demokratiese waardes van menswaardigheid, gelykheid en vryheid."

\section{Perspektiewe op die Suid-Afrikaanse demokrasie}

1993 Grondwet, kyk Dugard Rights 191-195.

27 A 1(a).

28 A 1(b).

29 A 1(c).

30 A 1(d). 


\subsection{Demokrasie}

Dit is opmerklik dat die begrip demokrasie in al drie die bespreekte gedeeltes voorkom. In die Aanhef figureer dit twee keer in sy adjektiwiese vorm "demokratiese"; in artikel 1(a) word gekonstateer dat Suid-Afrika 'n demokratiese staat is, en in artikel 7(1) word die Handves van Regte getipeer as die hoeksteen van die demokrasie in Suid-Afrika en word daar gesê dat hierdie Handves die "demokratiese waardes van menswaardigheid, gelykheid en vryheid" in Suid-Afrika bevestig. Uit laasgenoemde formulering wil dit voorkom of die waardes van menswaardigheid, gelykheid en vryheid aanduidings bied van 'n demokrasie. Alhoewel die term "demokrasie" so wyd is dat die bruikbaarheid daarvan soms betwyfel word, kan daar geen twyfel daaroor bestaan dat demokrasie as 'n kernwaarde van die nuwe bedeling voorgehou word nie. ${ }^{31}$

\subsection{Die soort demokrasie}

Die demokrasie wat in Suid-Afrika gevestig word, is een wat gegrond is op die oppergesag van die Grondwet en die heerskappy van die reg. ${ }^{32}$ Die 1996 Grondwet self geld as Grundnorm waaraan enige regsvoorskrif of optrede gemeet moet word, soos blyk uit artikel 2:

Hierdie Grondwet is die hoogste reg van die Republiek; enige regsvoorskrif of optrede daarmee onbestaanbaar, is ongeldig, en die verpligtinge daardeur opgelê, moet nagekom word.

31 Regter Chaskalson, President van die Konstitusionele Hof, het in sy openingsrede by die Conference on Legal Theory wat in September 1997 by RAU gehou is, na demokrasie verwys as die "founding value" van die die nuwe bedeling, 'n tipering wat weer eens op 'n vervlegting van 'n grondslag en 'n waarde dui.

32 A 1(c). 
Die soort demokrasie wat in die Grondwet ingestel word, dien homself aan as een wat sy legitimering in die wil van die mense vind. Dit blyk uit die Aanhef waar verklaar word dat

Ons, die mense van Suid-Afrika, [ ... ], [ ... ] neem deur ons vryverkose verteenwoordigers, hierdie Grondwet aan as die hoogste reg van die Republiek [...]

Vir diegene wat bekend is met die konstitusie van die VSA is die eggo onmiskenbaar:

We the People of the United States, in Order to make a more perfect Union, establish Justice, insure domestic Tranquility, provide for the common defence, promote the general Welfare, and secure the Blessings of Liberty to ourselves and our Posterity, do ordain and establish this Constitution for the United States of America. ${ }^{33}$

Albei hierdie formulerings gee uitdrukking aan 'n opvatting dat die wil van die mense die basis van 'n grondwet daarstel. Tegnies word daar na so 'n opvatting verwys as 'n teorie van volksoewereiniteit, en daar word verskillende weergawes daarvan aangetref. 'n Gewilde variant daarvan is die opvatting dat die staat sy gesag ontleen aan die sluiting van 'n sosiale verdrag of kontrak. Hierdie verdragsbeskouing beleef vreemd genoeg in die laat-twintigste eeu ' $n$ gewildheidsherlewing ${ }^{34}$ en daar word ook met instemming daarna verwys deur sommige skrywers wat kommentaar lewer op die 1996 Grondwet. ${ }^{35}$ Sosiale verdragsdenke het eweneens vele variasies, en die vernaamste figure wat daarmee geassosieer word, is Locke, Rousseau en Pufendorf. ${ }^{36}$ Ten spyte van die verskillende verskyningsvorme daarvan is 'n sentrale leerstuk van hierdie teorie dat vrye enkelinge ter wille van hul voortbestaan en same-lewing ooreenkom om iets van hul eie vryheid af te staan en om gesag oor 'n gedeelte van hul lewe aan 'n staat of soewerein oor te dra.

33 Peaslee Constitutions 1195.

34 Cliteur 1987 Philosophia Reformata 70.

35 Kyk bv Erasmus en De Waal 1997 Stell LR 36.

36 Kyk Van Eikema Hommes Trends vir 'n bondige uiteensetting van die verdragsteorieë van Hobbes (99-104), Locke (135-137), Pufendorf (115-116) en Rousseau (157-160). 
Alhoewel daar geargumenteer kan word dat die feit dat die 1996 Grondwet opgestel is in ooreenstemming met die Grondwetlike Beginsels van die 1993 Grondwet waarop daar ooreengekom is, en waaraan dit ingevolge artikel 71 van die 1993 Grondwet in die sertifiseringsproses geregtelik getoets is, hierdie verdragsteorie se toepaslikheid vir die 1996 Grondwet enigsins verhoog, kan kwalik ontken word dat so 'n teorie bloot as 'n fiksie funksioneer. ${ }^{37}$

Terwyl fiksies soms 'n nuttige funksie in die regswêreld vervul, ${ }^{38}$ is dié een oor die sosiale verdrag ongelukkig nie so 'n skadelose fiksie of onskuldige rasionalisasie as wat dit mag lyk nie. Chaplin ${ }^{39}$ wys tereg daarop dat die ontoereikendheid van 'n fundamentele aanname van die klassieke liberale tradisie al hoe duideliker in onlangse politieke besinning besef word. Hierdie aanname is naamlik dat die hoofprobleme van die politieke filosofie herleibaar is tot die enkelvoudige verhouding tussen die staat en die individu:

Philosophical reflection has for too long been preoccupied with a cluster of dilemmas arising from this relationship: how to derive the authority of the state from the individual, how to render the state accountable to individuals, or how to protect the individual against the state.

Volgens Chaplin word daar toenemend besef dat daar nie bevredigend op hierdie probleme antwoorde verskaf kan word as daar nie polities rekening gehou word met die omvattende terrein van sosiale verhoudinge en met gemeenskappe wat naas die individu en die staat bestaan nie. In hierdie redusering van staatkundige en regsvraagstukke tot 'n enkelvoudige verhouding tussen die staat en die individu, word belangrike vraagstukke óf uit die oog verloor óf op 'n verkeerde wyse gekonsipieer. Van die sake wat ooreenkomstig so 'n beskouing heel onbevredigend hanteer word, is die plek van

37 Kyk Jolowicz Lectures 13 wat die sosiale verdragsteorie as 'n "useless fiction" tipeer. Die swakheid van hierdie teorie is volgens hom onder meer daarin geleë dat dit poog om 'n regverdiging vir die reg te bied deur 'n beroep te doen op die reg, iets wat logies ontoelaatbaar is.

38 Kyk Van Eikema Hommes Elementaire Grondbegrippen 444-448 wat nut in sogenaamde praktiese of regstegniese fiksies sien, maar teoretiese of wetenskaplike fiksies verwerp. 
die sogenaamde nie-siviele privaatreg in die regstelsel asook 'n verrekening van die wyse waarop die burgerlike samelewing in 'n moderne demokrasie funksioneer. In die bestek van hierdie artikel kan daar nie verder hierop ingegaan word nie en moet daarby volstaan word om demokrasie te assosieer met "'n samelewing waarin regering gevestig is op die wil van die bevolking"40 en waarby die verteenwoordigingsbeginsel 'n belangrike rol speel. ${ }^{41}$

Die feit dat regering gevestig is op die wil van die mense, hou nie in dat die wil van die meerderheid sonder meer die deurslag gee nie. Die demokrasie wat in die bedeling ná 1994 in Suid-Afrika gevestig is, is een wat berus op 'n onderskrywing van konstitusionalisme. Dit wat Davis, Chaskalson en De Waal ${ }^{42}$ in verband met die 1993 Grondwet gesê het, is net so waar van die 1996 Grondwet, naamlik:

[...] the new South African Bill of Rights will accord greater weight to certain rights than the decisions of Parliament, notwithstanding the latter's ostensible democratic pedigree. In short, South Africans will bind themselves to certain values which trump the output of a transient legislature.

\section{3 "Demokrasie" en "demokratiese samelewing"}

Ten spyte daarvan dat daar sowel in die Aanhef as in artikel en 7(1) op een of ander wyse van demokrasie sprake is, is alles tog nie so eenduidig in 1(a) as wat dit met die eerste oogopslag mag voorkom nie.

Aan die een kant vermeld artikel 1(a) ondubbelsinnig dat Suid-Afrika "'n demokratiese staat" is wat onder meer op 'n waarde van "'n veelparty-stelsel van demokratiese regering" gegrond is. Aan die ander kant vestig die Aanhef die aandag daarop dat die vrygekose verteenwoordigers van die bevolking hierdie Grondwet met 'n aantal

39 Sphere Sovereignty 104.

40 Aangehaal uit die Aanhef tot die 1996 Grondwet.

41 Kyk Hommes 1978 TSAR 49. 
doelstellings aangeneem het. Hierdie doelstellings sluit onder meer die volgende in, naamlik om: 'n samelewing gegrond op demokratiese waardes, maatskaplike geregtigheid en basiese menseregte te skep; die grondslag vir 'n oop en demokratiese samelewing te lê, en 'n verenigde en demokratiese Suid-Afrika te bou. Hier bemerk 'n mens iets van die spanningsverhouding tussen "is" en "word": Suid-Afrika is 'n demokratiese staat, maar 'n demokratiese samelewing moet nog verwesenlik word.

Hierdie spanning tussen wat ' $n$ staat is en wat ' $n$ samelewing moet word, is analoog aan 'n nog belangriker dialektiese verhouding in die 1996 Grondwet. Dit is naamlik die spanningsverhouding tussen die waardes in artikel 1(a) en 7(1) van die 1996 Grondwet.

\section{$5 \quad$ Die dialektiek tussen artikels 1(a) en 7(1)}

Wanneer artikels 1(a) en 7(1) vergelyk word, blyk dit dat die verwysing na menswaardigheid onveranderd in albei hierdie artikels voorkom. Hier kan daarop gewys word dat die 1993 Grondwet die klem op vryheid en gelykheid laat val het, en nie menswaardigheid direk as een van die kernwaardes van daardie Grondwet vermeld het nie. Terwyl die invoeging van die waarde van menswaardigheid in die 1996 Grondwet iets nuuts in Suid-Afrika is, moet daarop gelet word dat menswaardigheid in die Grundgesetz van die Federale Republiek van Duitsland as die primêre mensereg beskou word en dat dit ten grondslag lê aan die inhoud en betekenis van alle grondwetlike norme. $^{43}$

So ver dit gelykheid en vryheid aangaan, is daar egter verskille tussen hierdie artikels aan te merk. Waar artikel 1(a) dit gehad het oor "die bereiking van gelykheid" en "die uitbou van menseregte en vryhede", is daar in artikel 7(1) bloot sprake van "gelykheid" en "vryheid". Die formulering van artikel 1(a) gee blyke van iets prosesmatigs. Dit gee uitdrukking daaraan dat gelykheid en vryheid nie iets is wat as 't ware met 'n pennestreep

42 Democracy and Constitutionalism 1.

43 A 1(1) en (2); De Wet 1995 SAJHR 34. 
by die aanvaarding van 'n nuwe grondwet intree sodra daar plegtig verklaar is dat almal gelyk en vry is nie.

Terwyl die bereiking van gelykheid en die uitbouing van menseregte en vryhede in artikel 1(a) oogmerke is wat in die verloop van tyd verwesenlik moet word, laat die formulering in artikel 7(1) niks blyk van iets prosesmatig nie. Hier het 'n mens te make met waardes, en die verwerkliking daarvan staan nie op die voorgrond nie. Alhoewel dit nie maklik is om 'n juiste benaming daarvoor te kry nie, sal voortaan (ter onderskeiding van hierdie proses-beskrywing) daarna verwys word as omskrywings wat dui op 'n toedrag van sake of op 'n toestand.

Terwyl menswaardigheid, gelykheid en vryheid waardes is, is die bereiking van gelykheid en die uitbou van menseregte en vryhede oogmerke wat in toenemende mate verwerklik moet word.

Op grond van die veronderstelling dat die Grondwet 'n eenheid vorm en koherensie vertoon, sou aanvaar kon word dat die strekking van bogenoemde formulerings óf dieselfde is óf dat dit ten minste versoenbaar met mekaar behoort te wees. Die formulering in artikel 7(1) van vryheid as toestand en gelykheid as toestand plaas die aksent egter aanmerklik anders as "die bereiking van gelykheid" en "die uitbou van menseregte en vryhede" van artikel 1(a).

Aan watter van hierdie formulerings behoort daar voorkeur verleen te word? Kan daar tekstuele of kontekstuele argumente aangevoer word wat die skaal laat swaai in die rigting van die een of die ander van hierdie formulerings?

In 'n poging om duidelikheid hieroor te verkry sal hierdie formulerings weldra eers intertekstueel met analoë formulerings vergelyk word. Daarna sal daar oorgegaan word tot 'n tekstuele ondersoek. Die oogmerk hiermee sal wees om na te gaan of een van hierdie twee formulerings, die prosesmatige of toestand-beskrywing, tekstueel beduidend sterker gekorroboreer word as die ander. Sou dit die geval wees, sou die vermoede 
bestaan dat dit die hooflyn in die Grondwet verteenwoordig so ver dit gelykheid en vryheid aangaan. Sou albei gekorroboreer word, moet aanvaar word dat die Grondwet hier 'n ingeboude dialektiek vertoon. Vertolkers daarvan sou hulle dan op enige van die twee formulerings ("lyne" of "pole") kon beroep, en dit sal die taak van die howe wees om in bepaalde kontekste een van hierdie twee lyne te kies. ${ }^{44}$

Na my mening hou hierdie vraagstuk verband met die vraag watter tipe staat die 1996 Grondwet daarstel, 'n regstaat of 'n sosiale demokrasie. Sou die hooflyn van die Grondwet in ooreenstemming wees met die artikel 7(1) formulering, kan dit daarop dui dat Suid-Afrika 'n regstaat in die liberale tradisie is. Sou die hooflyn egter aansluit by die artikel 1(a) formulering, dui dit in die rigting daarvan dat die 1996 Grondwet Suid-Afrika tot 'n sosiale demokrasie (ook genoem 'n sosiaalstaat of 'n sosiale versorgingstaat) stempel. Die "toestand-definisies" sluit met ander woorde aan by 'n tradisionele, liberale regstaatbedeling, terwyl die prosesmatige definisies weer aansluiting vind by die idee van 'n sosiale demokrasie.

Voordat die verskillende argumente vir en teen 'n artikel 1(a) en 'n artikel 7(1) lesing van die Grondwet uiteengesit en teen mekaar opgeweeg sal word, is dit nodig om kortliks (en daarom uiteraard ook baie veralgemenend) die hele vraagstuk in ruimer perspektief te stel. In hierdie verband sal aandag geskenk word aan

- die "oop plek" met betrekking tot die tipering van die soort staat wat Suid-Afrika onder die 1996 Grondwet is

- tersaaklike filosofiese oorwegings, insluitende verskillende mens-, samelewings- en staatsbeskouings.

\section{Die "oop plek": regstaat of sosiale demokrasie?}

44 Die bespreking hieronder sal toegespits word op die verskillende formulerings van die waardes in artikels 1(a) en 7(1) en daar sal nie binne die bestek van hierdie uiteensetting ingegaan kan word op 
Terwyl die 1993 Grondwet eksplisiet daarna verwys het dat die Suid-Afrikaanse staat 'n regstaat ${ }^{45}$ (of sogenaamde "constitutional state") is, ${ }^{46}$ kom hierdie benaming nie eksplisiet in die 1996 Grondwet voor nie. ${ }^{47}$ Moet hieruit afgelei word dat die 1996 Grondwet 'n koerswysiging wou teweegbring en dat die kort geskiedenis van regstaatlikheid in SuidAfrika wat met die 1993 Grondwet ingelui is, met die weglating van hierdie woorde afgesluit is?

Aan die ander kant is daar voorgestel dat die stigtingsartikel van die 1996 Grondwet pertinent na Suid-Afrika moes verwys as 'n sosiale demokrasie. Du Plessis ${ }^{48}$ se voorstel in hierdie verband was:

South Africa is a sovereign social democracy/social democratic state [...]

Sodanige voorstel is egter nie in die finale formulering van die 1996 Grondwet opgeneem nie. Nogtans gebeur dit meermale dat daar sonder verdere beredenering in resente konstitusionele literatuur na Suid-Afrika as 'n sosiale demokrasie verwys word. ${ }^{49}$

Die feit dat die 1996 Grondwet nie eksplisiet is in hierdie verband nie, maar die kwessie ooplaat en glad nie een van die twee terme gebruik nie, bring mee dat hierdie vraagstuk substantief beoordeel moet word. Daar is voorstanders van albei standpunte. Enersyds is

die vraagstuk van die dialektiese verhouding tussen vryheid en gelykheid as sodanig nie. Kyk hieroor Du Plessis 1997 Stell LR 185.

45 Kyk Van Wyk 1985 TSAR 153-157 vir 'n oorsig oor die idee van formele en materiële regstaatlikheid. Hommes 1978 TSAR 42-52 plaas die idee van die regstaat in wyer filosofiese perspektief en vergelyk dit met die sosiaalstaat.

46 De Waal 1995 SAJHR 4 wys daarop dat die verwysing na 'n regstaat in die Voorrede of Aanhef tot die 1993 Grondwet voorkom en as sodanig (ingevolge a 232(4) van die 1993 Grondwet) nie deel van die Grondwet uitmaak nie. Dit maak van hierdie formulering 'n onafdwingbare (hoewel nie onbelangrike) konstitusionele aanwysing of direktief.

47 De Waal 1995 SAJHR 4 was die weglating van die verwysing na 'n regstaat in die 1996 Grondwet te wagte. Die verwysing na ' $n$ regstaat, sonder dat daar eksplisiete tekstuele teenwigte vermeld word, kon volgens hom tot ongewenste gevolge aanleiding gee. Dit sou die skaal laat swaai in die rigting van 'n beklemtoning van individuele vryheid.

481996 Stell LR 8. Hy is van mening dat die feit dat gelykheid met vryheid in die konsep 1996 Grondwet gejukstaponeer word daarop dui dat Suid-Afrika 'n sosiale demokrasie is. 
daar diegene wat aanvoer dat Suid-Afrika wesenlik steeds 'n regstaat is. Andersyds is daar diegene wat nie huiwer om Suid-Afrika 'n sosiale demokrasie te noem nie.

'n Eksponent van die eerste van hierdie opvattings is Venter. ${ }^{50}$ Hy voer aan dat, wanneer daar ondersoek ingestel word na die aan- of afwesigheid van die materiële kenmerke van 'n regstaat in Wet 108 van 1996, dit blyk dat die kenmerke van die tipiese regstaat inderdaad steeds in hierdie Grondwet voorkom. In hierdie verband kan gewys word op die erkenning van die oppergesag van die reg; die ondubbelsinnigheid van die reg; toewyding aan die reg, regterlike beskerming en 'n verbod op gesagskonsentrasie; die uitoefening van owerheidsgesag ingevolge wetgewing wat in ooreenstemming met die Grondwet aangeneem is; grondwetlike beskerming van fundamentele regte en 'n verbod op terugwerkendheid; gewaarborgde vryheid, geregtigheid en regsekerheid; gelykheid van die reg, die verspreiding van gesag; regterlike kontole oor die uitoefening van gesag asook die meetbaarheid, voorspelbaarheid en berekenbaarheid van die optrede van die uitvoerende gesag. Die feit dat die term regstaat nie eo nomine vermeld word nie, beteken volgens hom nie dat die einde van die konsep van regstaatlikheid met hierdie weglating aangebreek het nie. ${ }^{51}$ Hiervolgens behoort die weglating van die term nie die verdere ontwikkeling van die tradisie van regspraak wat na 1994 ontwikkel het en wat op regstaatlikheid klem gelê het, te strem nie. ${ }^{52}$ Venter gee egter toe dat die aanwesigheid van elemente wat kenmerkend is van 'n sosiale versorgingstaat in die 1996 Grondwet

49 Kyk Van der Merwe Roman-Dutch Law 14: "Social democracy came to South Africa late, with the advent of democratic constitutionalism a mere three years ago, and was also the result of ideological compromise."

50 Kyk 1998 PER 4-17.

51 In hierdie verband moet in gedagte gehou word dat die 1993 Grondwet dit in die Aanhef eksplisiet as die taak van die Grondwetlike Vergadering aangestip het om "'n demokratiese en soewereine regstaat" tot stand te bring. Erasmus en De Waal Stell LR 32 wys daarop dat dit uit die Konstitusionele Hof se sertifiseringsuitspraak blyk dat hierdie hof in sy toetsing van die vraag of die 1996 Grondwet aan die grondwetlike beginsels in Bylae 4 van Wet 200 van 1993 voldoen, ondubbelsinnig aangetoon het dat die genoemde grondwetlike beginsels doelgerig en teleologies aangewend moet word om uitdrukking te gee aan die verbondenheid tot die totstandbrenging van 'n nuwe orde wat gebaseer is op "a sovereign and democratic constitutional state" (In re: Certification of the Constitution of the Republic of South Africa 1996199610 BCLR 1253 (KH)).

52 In hierdie verband kan sydelings opgemerk word dat die feit dat daar in die 1996 Grondwet 'n verwysing na die rule of law voorkom, nie sonder meer beskou moet word as sou regstaatlikheid daardeur geïmpliseer word nie. Sommige outeurs (bv Erasmus en De Waal 1997 Stell LR 33) gebruik 
aanwesig is wat nie so maklik met die idee van regstaatlikheid gerym kan word nie. ${ }^{53}$ Alles in ag genome kan Suid-Afrika volgens hom steeds as 'n regstaat geklassifiseer word.

Aan die ander kant is daar diegene wat sonder breedvoerige beredenering aanvaar dat die feit dat daar geen eksplisiete verwysing daarna is dat die Republiek van Suid-Afrika 'n sosiale demokrasie is nie, nie beteken dat dit nie inderdaad die geval is nie. Wat presies onder 'n sosiale demokrasie verstaan moet word, is moelik om te definieer. In die eerste plek word meerdere terme gebruik. Afgesien van "sosiale demokrasie" word daar ook gepraat van 'n "sosiaalstaat" en 'n "sosiale versorgingstaat" of "welsynstaat".

Terwyl 'n regstaat gekenmerk word deur 'n erkenning van die oppergesag van die reg en ooreenkomstig sy liberalistiese agtergrond poog om die individu te beskerm teen staatsabsolutisme, is 'n sosiale demokrasie nie so defensief ingestel nie. Inteendeel, dit is ingestel op aktiewe optrede. Stern ${ }^{54}$ stel dit soos volg:

The mandate of a social state is one of action; it is a call to foster social integration with the help of the state, the latter having to be alert to social crisis and conflict and to share the responsibility to putting things in their proper order.

Die aktiewe oriëntering van 'n sosiale demokrasie kan gesien word in die funksies wat dit vervul met betrekking tot sosiale herskikking, onder meer met betrekking tot beplanning, rigtinggewing en ontwikkeling. Dit is 'n staat wat wil voorsiening maak vir die behoeftes van die gemeenskap. As sodanig het dit 'n hele aantal funksies bygekry wat volgens tradisionele liberale opvatting nie deel van die staatstaak uitmaak nie. Daar word in 'n sosiale demokrasie besonder sterk klem gelê op gelykheid en op distributiewe geregtigheid. 'n Groter mate van distributiewe geregtigheid kan net verkry word wanneer die publieke sfeer sy invloed op die private sfeer kenbaar maak. Waar dit by 'n regstaat

formulerings wat hierdie begrippe gelykstel, maar dit is ten onregte. Kyk hieroor Ferreira Staatsregtelike Onregmatigheid 347-350.

53 Venter 1998 PER 15. 
primêr gaan om die beskerming van die individu teen staatsabsolutisme, gaan dit by die sosiaalstaat om aktiewe "Teilhabe" as reg en as aanspraak. ${ }^{55}$

Soms word daar gepoog om elemente van sowel die regstaat as die sosiale demokrasie te verbind. In so 'n geval word daar verwys na 'n "sozialer Rechtsstaat". ${ }^{5}$ In 'n sosiale regstaat word daar gepoog om die burgerlike en politieke regte wat kenmerkend is van 'n regstaat te versoen met die beskerming van sosio-ekonomiese regte en belange wat tipies is aan 'n sosiaalstaat. Skrywers soos Hommes ${ }^{57}$ is van mening dat daar nie 'n skerp teenstelling bestaan tussen 'n regstaat en 'n sosiaalstaat nie. Ter handhawing van hierdie standpunt word hy egter genoop om die staat se betrokkenheid by sosio-ekonomiese aangeleenthede te relegeer tot veranderlike sekondêre staatsdoeleindes wat afhanklik is van die kultuurhistoriese ontwikkelingsniveau van 'n bepaalde staat. Of die staat se taak op sosio-ekonomiese gebied nog in die laat-twintigste eeu in 'n pluralistiese, geïndustrialiseerde en tegnologies hoogs ontwikkelde samelewing as iets sekondêrs getipeer kan word, is egter debatteerbaar.

Ter ondersteuning van die argument dat die 1996 Grondwet 'n sosiale demokrasie daarstel, kan gewys word op die:

- groter prominensie van sosio-ekonomiese regte in die 1996 Grondwet

- belangrike veranderings ten opsigte van horisontale werking van die 1996 Grondwet in vergelyking met die 1993 Grondwet

- besondere eise wat daar aan die owerheid gestel word om 'n aktiewe rol in sosiale transformasie te speel, en

- $\quad$ sterk beklemtoning wat gelykheid in die Grondwet te beurt val.

541982 TSAR 247.

55 Kyk Hommes 1978 TSAR 51.

56 Die Federale Republiek van Duitsland word in a 20 van sy Grundgesetz getipeer as 'n demokratiese en sosiale federale staat. A 28(1) bepaal voorts dat die die grondwetlike ordening in die Länder ooreen moet stem met die beginsels van die "republikanischen, demokratischen und sozialen Rechtsstaats" soos wat dit in die Grundgesetz gedefinieer is. 
Hierdie kwessies kom weer aan die orde nadat die ruimere filosofiese kader waarbinne hierdie vraagstukke tuishoort, geskets is.

\section{$7 \quad$ Die ruimere filosofiese kader: mens-, samelewings- en staatsbeskouing}

Opvattings oor die staat en oor die staatstaak hou verband met kwessies van mens- en van samelewingsbeskouings. Die eeuoue debat oor die vraag of die mens primêr 'n individu of primêr 'n sosiale wese is, is steeds in die twintigste eeu onopgelos, en maak homself kenbaar in die regsfilosofie. 'n Uitloper van hierdie debat kan gesien word in die meningsverskille tussen die libertarians en kommunitariste in die twintigste eeu.

Aan die een kant is daar steeds diegene wat in die lyn van die klassieke Liberalisme die mens primêr as individu beskou, en wat - in samehang daarmee - 'n baie hoë premie plaas op die mens se persoonlike vryheid en (nie verrassend nie) op die beskerming van privaat eiendomsreg en van die private sfeer oor die algemeen. Hierdie individualisme hang gewoonlik saam met 'n beskouing dat die staatstaak baie eng opgeneem word. Die standpunt word ingeneem dat die staat primêr daar is om orde te handhaaf, om oortredings teen die regsorde te straf en om aangebore menseregte (soos die regte op lewe en vryheid) asook eiendom te beskerm. Die staat moet ook die regsekerheid verskaf wat in die natuurstaat ontbreek. Dit word bewerkstellig deur algemene wetgewing, onafhanklike regspraak en die uitvoering van vonisse deur middel van kollektiewe dwang. Van hierdie soort staatsbeskouing word gewoonlik as 'n sogenaamde "nagwagstaat" gepraat, aangesien die doel van die staat hiervolgens afgestem is op die beskerming van menseregte en van eiendom. Dit is baie opmerklik dat die staat hier 'n oordrewe privaatregtelike beklemtoning het. ${ }^{58}$ Alhoewel so 'n staatsbeskouing reeds sedert die Industriële Revolusie onder druk is, en alhoewel die geskiedenis sedert die middel van die negentiende eeu van 'n sterk verruiming van die staatstaak getuig, is daar veral in vryemarkkringe steeds sterk voorstanders van hierdie standpunt. Daar moet

571978 TSAR 51-52.

58 Kyk Hommes 1978 TSAR 45 vir 'n veralgemening oor die staatsopvattings van denkers soos Locke, Montesquieu, Kant en Humboldt. 
opgemerk word dat so 'n beskouing, terwyl dit die beskerming van die individu teen staatsabsolutisme op die oog het, sosio-ekonomiese verhoudings oorlaat aan die werking van die meganisme van die vrye mark. Die kernwaarde hier is vryheid eerder as gelykheid.

Daarteenoor staan opvattings wat gekant is teen die oordrewe individualisme van bogenoemde beskouing en wat van mening is dat die mens primêr 'n sosiale wese is. In die twintigste eeu argumenteer die kommunitariste byvoorbeeld dat die mens se identiteit nie pre-sosiaal is nie, maar juis gevorm is deur die gemeenskap, plek en tyd. Saam met hierdie anderse mensbeskouing gaan 'n ander staatsbeskouing. Hier is nie bloot plek vir die sogenaamde nagwagstaat nie, maar vir 'n staat wat die gemeenskap aktief bestuur en verander op weg na groter sosiale geregtigheid. Die veranderde sosio-ekonomiese situasie in 'n geïndustrialiseerde samelewing noodsaak 'n veel groter rol vir die staat op sosio-ekonomiese terrein. ${ }^{59}$

Hierdie debat is van groot belang vir die vraagstuk rondom die sogenaamde horisontale werking van 'n grondwet asook vir hoe die verhouding tussen die publiekreg en privaatreg daar uitsien. Vir die klassieke liberalis is die privaatreg ver verwyder van die publiekreg. ${ }^{60}$ Dit is 'n terrein waarvan die staat met sy aanmatiging van beheer en reguleringsmaatreëls so ver as moontlik moet wegbly, en as dit dan omdat dit werklik nie anders kan nie, wel 'n rol moet speel, moet hierdie rol so klein wees as wat moontlik en nodig is.

Diegene met 'n minder individualistiese mens- en samelewingsbeskouing voel heeltemal anders hieroor. Uit sowel sosialistiese as kommunitaristiese oogpunt beskou bestaan die samelewing nie maar net as 'n klomp los individue nie. Die samelewing is eweneens nie maar net die toevallige dekor waarteen die individu se lewe afspeel nie. Hierdie samelewing, met sy ongelykhede en onbillikhede, wat as 't ware die mens konstitueer en

59 Hommes 1978 TSAR 45-46.

60 Dit is opmerklik dat ook die tradisie van die Romeins-Hollandse reg wat so 'n diepgaande invloed op die Suid-Afrikaanse regstelsel uitgeoefen het, 'n sterk privaatregtelike oriëntering vertoon. 
aan hom sy identiteit gee, word dikwels gekenmerk deur ongelykhede en is iets wat verander moet word. Die instansie wat belas is met hierdie verandering is die staat. Die staat word dan gewoonlik (in lyn met Aristoteles se ou opvatting ${ }^{61}$ ) beskou as die oorkoepelende, omvattende en allesbeheersende samelewingsverband. Hierdie universalistiese beskouing hou in dat ander samelewingsverbande hulle in die laaste instansie moet skik na na die wil van die staat. In die rig en in die verandering van gemeenskappe is die reg by uitnemendheid die instrument waardeur regeerders die samelewing manipuleer. 'n Mens het dus hier te make met die idee van "social engineering". Dit spreek vanself dat wanneer die staat dit op hom neem om deur middel van die reg die rol van sosiale ingenieur te speel, die onderskeid tussen die private en die publieke sfeer nie meer so duidelik sal wees as wat dit in 'n nagwagstaat sou wees nie. Die private sfeer is nie insulêr of iets wat onttrek is van die publieke sfeer nie. Inteendeel, binne die raamwerk van so 'n opvatting maak die publieke sfeer sy invloed duidelik op die private sfeer kenbaar.

Terwyl die nagwagstaat en die allesbeheersende staat as 't ware radikaaltipes van staatsbeskouings genoem kan word, verteenwoordig nie een daarvan die hooflyn van staatkundige denke in die laat twintigste eeu nie. As bogenoemde twee staatsbeskouings die uiterstes sou verteenwoordig, dan sou 'n mens binne daardie kontinuum die regstaat en die sosiaalstaat daartussen aantref. Die regstaat het verbintenisse met die Liberalisme en staan nader aan die nagwagstaat, alhoewel dit hoegenaamd nie daarmee identies is nie. Die sosiaalstaat is eweneens nie die allesoorheersende staat van die kommunistiese praktyk nie, maar staan nader aan daardie punt van die kontinuum as die regstaat. ${ }^{62}$

Daar moet in gedagte gehou word dat die ideologiese stryd in Suid-Afrika tydens die totstandbrenging van sowel die 1993 as die 1996 Grondwet 'n eie stempel op die debatte rondom die beskerming van fundamentele regte afgedruk het. Van die drie ideologiese

61 Kyk Van Niekerk Regering en Staatsgesag 146.

62 De Wet 1995 SAJHR 33-34 stel dat 'n sosiale regstaat poog om in 'n pluralistiese, industriële samelewing 'n middeweg te vind tussen 'n Klassieke-Liberale en 'n Marxisties-Leninistiese stelsel. 
spanningsverhoudings wat Du Plessis en Corder $^{63}$ bespreek, te wete dié van die stryd tussen Libertarianism en Liberationism, dié tussen progressivisme en tradisionalisme, en dié tussen feminisme en patriargie, is eersgenoemde myns insiens die tersaaklikste vir die bespreking oor die spanningsverhouding tussen die waarde-uitsprake in die 1996 Grondwet. ${ }^{64}$

Teen hierdie agtergrond kan teruggekeer word na die beredenering van die probleem met betrekking tot watter van die waardeformulerings in artikel 1(a) of 7(1) voorkeur behoort te geniet. Eerste sal intertekstuele argumente aan die orde kom. Daarna sal tekstuele argumente bespreek word.

\section{$8 \quad$ Intertekstuele eggo's}

Die waardes in artikel 7(1), te wete dié van menswaardigheid, gelykheid en vryheid, herinner enigsins aan die slagkreet van die Franse revolusie, naamlik "vryheid, gelykheid en broederskap," met die klaarblyklike vervanging van die seksistiese "broederskap" met die nie-seksistiese waarde van menswaardigheid.

Die Aanhef van die Handves van die Verenigde Nasies vermeld twee van die drie waardes wat in artikel 7(1) voorkom, te wete dié van menswaardigheid en gelykheid. Dit lui soos volg:

We the peoples of the United Nations determined [...] to reaffirm faith in fundamental human rights, in dignity and worth of the human person, in the equal

63 Du Plessis en Corder Bill of Rights 22-39.

64 Daar is ook ander tiperings van die ideologiese spanningsverhoudings. Van Wyk Constitution 157 voer aan dat die "libertarian"-"liberationist" tipering nie wyd genoeg is om reg te laat geskied aan die verskillende benaderings tot die kwessie van mag in die Suid-Afrikaanse konteks nie. Volgens Van Wyk is daar ten minste vier benaderings hiertoe onderskeibaar. Aan die een kant van die spektrum was daar die sterk voorstanders van magssentralisasie en aan die ander kant die sterk voorstanders van magsdesentralisasie. Tussen hierdie pole was daar voorstanders van 'n liberale demokrasie en van federalisme. 
rights of men and women and of nations large and small, [ ... ] have resolved to continue our efforts to accomplish these aims.

Die feit dat die verskillende waardes wat in die VN Handves genoem word, as doelwitte ("aims") beskryf word, het tot gevolg dat hierdie interteks nie as eenduidige steun vir 'n artikel 7(1) lesing beskou kan word nie, maar as 't ware halfpad tussen 'n artikel 7(1) en (1)(1) lesing staan.

Ook die African Charter of Human and Peoples' Rights het in sy voorrede 'n analoë bepaling wat stel dat hierdie handves onder meer opgestel is met inagneming van:

[ ... ] the Charter of the Organization of African Unity, which stipulates that "freedom, equality, justice and dignity are essential objectives for the achievement of the legitimate aspirations of the African peoples; [ ...]

Die waardes wat in die voorrede van die African Charter voorkom, kom onveranderd voor in artikel 7(1) van die Grondwet. Die een ooglopende verskil is dat daar in die African Charter 'n verwysing na "justice" is, wat nie in artikel 7(1) voorkom nie. Ten spyte van die woordelikse ooreenkomste tussen artikel 7(1) en dié van die African Charter, het laasgenoemde teks tog ook veel gemeen met artikel1(a). Dit blyk uit die feit dat die vier waardes wat in die African Charter vermeld word, voorgehou word as oogmerke ("objectives") wat ter wille van die strewes ("aspirations") van Afrikane bereik moet word.

Alhoewel die verwagting gekoester is dat die Grondwet van Namibië moontlik intertekstuele getuienis sou oplewer so ver dit sowel die 1993 as 1996 Suid-Afikaanse Grondwet aangaan, het dit by ondersoek geblyk nie die geval te wees nie.

Samevattend kan gestel word dat die byhaal van intertekstuele getuienis die skaal nie in die rigting van óf die artikel 1(a) óf die artikel 7(1) formulering laat swaai nie. 


\section{Tekstuele argumente ten gunste daarvan dat artikel $7(1)$ die hooflyn verteenwoordig}

Die volgende argumente kan angevoer word ten gunste van die standpunt dat die formulering soos in artikel 7(1) die hooflyn verteenwoordig.

Dieselfde drieluik van menswaardigheid, gelykheid en vryheid kom onveranderd elders in die Grondwet voor. Dit is in artikel 36(1), waar die beperking van regte aan die orde kom en in artikel 39(1)(a) wat handel oor die uitleg van die Handves van Regte. Artikel 36(1) bepaal:

Die regte in die Handves van Regte kan slegs kragtens 'n algemeen geldende regsvoorskrif beperk word in die mate waarin die beperking redelik en regverdigbaar is in 'n oop en demokratiese samelewing gebaseer op menswaardigheid, gelykheid en vryheid, [...]

Artikel 39(1)(a) bepaal op sy beurt:

(1) By die uitleg van die Handves van Regte -

(a) moet ' $n$ hof, tribunaal of forum die waardes wat 'n oop en demokratiese samelewing gebaseer op menswaardigheid, gelykheid en vryheid ten grondslag lê, bevorder; [...]

Die formulering in artikel 7(1) geniet met ander woorde ondersteuning in die res van die Grondwet. Soos wedra sal blyk, is daar egter ook tekstuele getuienis tot die teendeel.

In soverre hierdie formulering met tradisionele, liberale regstaatdenke verband hou, moet opgemerk word dat daar in die Handves van Regte bepaalde regte beskerm word wat tipies met regstaatlikheid geassosieer word. Dit gaan hier oor die burgerlike en politieke regte, die sogenaamde blou regte, wat normaalweg nie aktiewe staatsoptrede verg nie. Hierdie regte respekteer die waardigheid en vryheid van die individuele persoon. 
Voorbeelde hiervan in die 1996 Grondwet is die reg op lewe, ${ }^{65}$ menswaardigheid, ${ }^{66}$ vryheid en sekerheid van die persoon, ${ }^{67}$ die reg om nie aan slawerny, knegskap en dwangarbeid onderwerp te word nie, ${ }^{68}$ die reg op privaatheid, ${ }^{69}$ vryheid van godsdiens, oortuiging en mening, ${ }^{70}$ vryheid van uitdrukking ${ }^{71}$ en vryheid van assosiasie. ${ }^{72}$

Dit blyk dus dat die formulering soos in artikel 7(1) nie geïsoleerd nie, maar wyd verspreid in die Grondwet voorkom.

\section{Tekstuele argumente ten gunste daarvan dat artikel 1(a) die hooflyn verteenwoordig}

\section{$10.1 \quad$ Inleidend}

Die formulering van artikel 1(a) met sy prosesmatigheid vind op sy beurt ook elders in die 1996 Grondwet weerklank. In hierdie geval berus die ooreenstemming nie soseer op woordelikse herhaling nie. Soos later aangetoon sal word, sluit die formulering in artikel 1(a) goed aan by die idee van "social engineering." ${ }^{73}$ Dit staan in die teken van die idee van maatskaplike transformasie waarin die staat en ook die burgerlike samelewing 'n belangrike rol te speel het. Die kruks van die argument ten gunste van 'n opvatting dat artikel 1(a) die hooflyn verteenwoordig, is geleë in:

- $\quad$ 'n ruim siening van die staatstaak

- maatreëls gemik op sosiale herskikking

- die rigting wat die Grondwet inslaan met betrekking tot sogenaamde horisontale werking van die Handves van Regte

65 A 11.

66 A 10.

67 A 12.

68 A 13.

69 A14.

70 A 15.

71 A 16.

72 A 18. 
- die sterk klem op gelykheid as die kernwaarde van die nuwe bedeling

- die beklemtoning wat die ontwikkeling van menslike potensiaal geniet.

\section{2 'n Ruim siening van die staatstaak}

Dit is duidelik dat die 1996 Grondwet geen nagwagstaat op die oog het nie. Daar is, inteendeel, heelwat aanduidings dat 'n baie aktiewe rol vir die staat in die vooruitsig gestel word so ver dit die bewerkstelliging van maatskaplike geregtigheid aangaan. Van die vernaamste bepalings wat in hierdie verband ter sake is, is die volgende:

- In die Handves van Regte, wat as die hoeksteen van die demokrasie in Suid-Afrika getipeer word, word daar van die staat verwag dat dit die regte in hierdie Handves "moet [...] eerbiedig, beskerm, bevorder en verwesenlik." ${ }^{74}$ Die staat moet met ander woorde aktief deelneem aan die skepping van 'n kultuur waarin fundamentele regte nie alleen beskerm word nie, maar ook verwesenlik word. Die bevordering en verwesenliking van die wye verskeidenheid regte wat in Hoofstuk 2 beskerm word, verg kennelik aktiewe owerheidsoptrede.

- In die verwerkliking van sosio-ekonomiese regte word daar meermale aktiewe optrede van die owerheid verwag. ${ }^{75}$

- Daar is meerdere aanduidings dat daar van die staat nie net verwag word om 'n bepaalde funksie te vervul nie, maar dat daar op die staat 'n verpligting gelê word om daardie funksie soos wat die geskiedenis verloop, in toenemende mate te vervul. ${ }^{76}$

Daar is eweneens aanduidings dat die aktiewe optrede van die staat die private sfeer nie onaangetas laat deur die openbare sfeer nie.

Hieruit blyk dit reeds dat die staatstaak ruim opgeneem word. Hier is nie van 'n nagwagstaat of minimale staat sprake nie, maar van 'n aktiewe staat. Daar word

Kyk par 10.3 hieronder.

Artikel 7(2) van die1996 Grondwet.

Kyk die bespreking van artikels 26 en 27 by par 10.3.4. (1) hieronder.

Kyk die bespreking by par 10.3.4 (3) hieronder. 
vervolgens aandag geskenk aan die verbandhoudende aangeleenthede van "social engineering" en van die horisontale werking van die Handves van Regte.

\section{3 "Social engineering" ter wille van maatskaplike geregtigheid}

\subsubsection{Die bewerkstelliging van maatskaplike geregtigheid}

Die 1996 Grondwet bevat 'n aantal artikels wat daarop dui dat dit daarop gemik is om die samelewing te verander en in 'n rigting van groter geregtigheid te stuur. Die Aanhef tot die Grondwet gee reeds 'n eksplisiete aanduiding hiervan wanneer daar pertinent vermeld word dat die Grondwet ten doel het om 'n samelewing te skep wat onder meer op maatskaplike geregtigheid ${ }^{77}$ gegrond is. In hierdie veranderingsproses wat die bewerkstelliging van maatskaplike geregtigheid op die oog het, word daar 'n besondere rol aan die staat as agent van verandering toegeken. Die werktuig waardeur die staat sodanige verandering teweegbring, is die reg.

Die bewerkstelliging van maatskaplike geregtigheid hou in dat daar van 'n onaanvaarbare toestand tot 'n regverdiger bestel beweeg moet word. Om groter maatskaplike geregtigheid te bewerkstellig, moet die posisie van (eertydse) benadeeldes en gemarginaliseerdes verbeter word. Daar moet 'n poging aangewend word om die uitbuiting van en onbillike dominasie oor die benadeeldes teen te gaan en te verhoed. Die oogmerk van maatreëls gemik op die bewerkstelliging van sosiale geregtigheid is om 'n billiker posisie vir die benadeeldes te beding in sosio-ekonomiese aangeleenthede. ${ }^{78}$ Dit mag inhou dat sodanige persone of kategorieë persone ontwikkel en bevoordeel moet word ten koste van diegene wat vroeër bevoordeel is. Dit bring mee dat die bevordering van maatskaplike geregtigheid in botsing mag kom met die waarde van gelykheid as toestand of toedrag van sake.

77 Simpson Law 39 omskryf maatskaplike geregtigheid as "a state of society in which a just distribution of good things is achieved". Waar geregtigheid tradisioneel individualisties opgeneem en benader is, word daar deur baie twintigste-eeuse denkers 'n sterker sosiale opvatting van geregtigheid gehuldig. 


\subsubsection{Die harmoniëring van sosiale herskikking met die waarde van gelykheid}

Na aanleiding hiervan ontstaan die vraag hoe die 1996 Grondwet te werk gaan om sosiale herskikking te harmonieer met die waarde van gelykheid, wat een van die kernwaardes van die 1996 Grondwet is. Die uitdaging waarvoor die grondwetskrywers te staan gekom het, was om die bevoordeling van eertydse benadeeldes nie voor te hou as uitsonderings op die gelykheidsbepaling nie, maar as 'n besondere verskyningsvorm daarvan. Uit die bespreking van artikels 9(2), 195(1), 217, 25(8), 26 en 27 sal dit duidelik word hoe die Grondwet hierdie probleem hanteer het. In die eerste vier gevalle berus die oplossing vir bogenoemde probleem op 'n bepaalde definisie van gelykheid.

\subsubsection{Oplossings aan die hand van ' $n$ bepaalde gelykheidsopvatting}

\section{(1) Artikel 9(2)}

Artikel 9 handel met gelykheid. Terwyl artikel 9(1) stel dat elkeen gelyk is voor die reg en dat elkeen die reg het op gelyke beskerming en voordeel van die reg, lui artikel 9(2) soos volg:

Gelykheid sluit die volle en gelyke genieting van alle regte en vryhede in. Ten einde die bereiking van gelykheid te bevorder, kan wetgewende en ander maatreëls getref word wat ontwerp is vir die beskerming of ontwikkeling van persone of kategorieë persone, wat deur onbillike diskriminasie benadeel is.

Alhoewel dit nie by hierdie naam genoem word nie, is dit hierdie artikel wat regstellende optrede in die Suid-Afrikaanse regstelsel magtig. ${ }^{79}$ Daar moet opgelet word dat daar hier van 'n veroorlowende bepaling sprake is, aangesien dit dui op maatreëls wat getref kan

78 De Wet 1995 South African Journal on Human Rights 39.

79 A 9(2) bou voort op Grondwetlike Beginsel 5 van die 1993 Grondwet. Enersyds stel hierdie beginsel dat die regstelsel die gelykheid van almal voor die reg en 'n regverdige regsproses moet verseker. Andersyds stel dit eksplisiet dat gelykheid voor die reg wette, programme of bedrywighede insluit 
word, en wat nie regtens aangeveg sal kan word op grond daarvan dat dit in stryd is met die algemene gelykheidsbepaling in artikel 9(1) nie.

Die dilemma met betrekking tot die harmoniëring van die gelykheidswaarde en die bevordering van maatskaplike geregtigheid word opgelos deur die begrip gelykheid prosesmatig te definieer. Gelykheid word met ander woorde nie voorgehou as iets wat maar net gebeur, intree of verwerklik word wanneer die Grondwet bepaal dat daar gelykheid voor die reg is nie. Dit is iets wat in 'n bepaalde konteks deur wetgewende en ander maatreëls aktief bewerkstellig moet word.

Die bewoording van artikel 9(2) toon 'n duidelike ideologiese oriëntasie. Die raamwerk waarbinne hierdie subartikel verstaan moet word, word eksplisiet aangegee. Die artikel is naamlik toegespits op die beskerming en bevordering van die belange van diegene teen wie daar (vroeër) onbillik gediskrimineer is. Dit toon met ander woorde 'n gemoeidheid met die gemarginaliseerdes. Die onuitgesproke konteks waarbinne hierdie formulering verstaan moet word, is dié van benadeling onder die apartheidsbedeling in Suid-Afrika.

Die maatreëls wat getref word om gelykheid te bevorder, word voorgehou as beskermings- en bevorderingsmaatreëls. Die woord bevordering sluit goed aan by die idee van "social engineering". Dit getuig met ander woorde van 'n oriëntasie wat die klem lê op aktiewe betrokkenheid van onder meer die owerheid om sosiale verandering te bewerkstellig. Woorde soos "benadeeldes", "beskerming", "bevordering" dui op 'n positiewe ingesteldheid teenoor regstellende optrede, en staan in teenstelling met uitdrukkings soos "omgekeerde diskriminasie" wat deur die teenstanders daarvan gebruik word om sodanige maatreëls te tipeer.

(2) Artikel 25(8)

wat ten doel het om die posisie van benadeeldes te verbeter, met inbegrip van dié wat op grond van ras, kleur of geslag benadeel is. 
Artikel 25(8) is eweneens 'n regstellende aksie-artikel. In hierdie geval is dit spesifiek afgestem op wetgewende en ander maatreëls met betrekking tot die bewerkstelliging van grond-, water- en verbandhoudende hervorming wat gemik is daarop om onderworpe aan die bepalings van artikel 36(1) "die gevolge van rassediskriminasie van die verlede reg te stel". Die invoeging van hierdie artikel dui daarop dat die bewerkstelliging van sodanige hervorming nie bloot aan die werking van die vrye mark oorgelaat word nie. Die staat kan deur wetgewende en ander maatreëls 'n rol daarin speel.

\section{(3) Artikel 195(1)}

Ook artikel 195(1)(i) gee blyke van 'n aktiewe owerheidsrol in die bewerkstelliging van sosiale verandering. Die artikel handel met die "waardes en beginsels" wat openbare administrasie beheers en wat van toepassing is op administrasie in enige regeringsfeer, staatsorgane en openbare ondernemings. ${ }^{80}$ Dit lui soos volg:

Openbare administrasie moet in die breë verteenwoordigend wees van die SuidAfrikaanse bevolking, met indiensnemings- en personeelbestuurspraktyke wat gebaseer is op vermoë, objektiwiteit, billikheid en die behoefte om die wanbalanse van die verlede reg te stel ten einde breë verteenwoordiging te bewerkstellig.

Hierdie artikel stel 'n norm daar vir die beoordeling van die graad van verteenwoordigendheid van die Suid-Afrikaanse bevolking in die openbare administrasie. Anders as in die geval van artikel 9(2) is hierdie subartikel gebiedend geformuleer. Die nastrewing en verwerkliking van breë verteenwoordiging word pertinent geplaas binne die konteks van 'n regstelling van die wanbalanse van die verlede. Dit hou direkte konsekwensies in vir indiensnemings- en personeelbestuurspraktyke.

'n Aantal kriteria moet aangelê word by hierdie indiensnemings- en personeelbestuurspraktyke, te wete vermoë, objektiwiteit, billikheid en 'n behoefte aan

80 A 195(2). 
regstelling van die wanbalanse van die verlede. Terwyl kriteria soos vermoë en objektiwiteit in die rigting van 'n merietebenadering neig, wil dit voorkom of die kriterium van die regstelling van die wanbalanse van die verlede potensieel met 'n merietebenadering in konflik mag kom. Die vermelding van potensieel botsende kriteria sal dit op die howe se weg plaas om uitsluitsel hieroor te gee wanneer sogenaamde regstellende optrede-aanstellings in die howe aangeveg word. Dit is goed denkbaar dat faktore soos vermoë en regstellingsbehoefte teen mekaar mag indruis.

\section{(4) Artikel 217(1)}

Artikel 217 is in sekere opsigte analoog aan artikel 195(1)(I). Subartikel (1) lê 'n verpligting op aan 'n staatsorgaan op nasionale, provinsiale of plaaslike regeringsvlak en aan enige ander instelling wat in nasionale wetgewing geïdentifiseer is om 'n verkrygingsbeleid te volg "wat regverdig, billik, deursigtig, mededingend en kostedoeltreffend is". Aan die ander kant stel subartikel (2) dat subartikel (1) nie staatsorgane en instellings belet om 'n verkrygingsbeleid toe te pas wat voorsiening maak vir voorkeurkategorieë by die toekenning van kontrakte en vir die beskerming of vooruitgang van persone of kategorieë persone wat deur onbillike diskriminasie benadeel is nie. Die vereiste word gestel dat sodanige beleid in nasionale wetgewing vasgelê moet word. $^{81}$

Terwyl subartikel (1) die elemente bevat wat gewoonlik met 'n liberale en vryemark georiënteerde samelewing geassosieer word, word hierdie oriëntering deur subartikel (2) gekwalifiseer. Alhoewel hierdie "uitsonderingsgevalle" nie gebiedend geformuleer is nie, maar bloot getipeer word as optrede wat nie grondwetlik belet word nie, is dit nogtans kenmerkend van 'n "social engineering" benadering, wat heelwat praktiese konsekwensies inhou. Dat so 'n benadering die eertydse benadeeldes aansienlik kan bevoordeel, lê voor die hand. Dat die potensiaal vir seksionele bevoordeling daarin opgesluit lê, is eweneens duidelik. Dit hou waarskynlik weer eens verband met 'n

81 A 217(3). 
beskouing van gelykheid as iets wat prosesmatig bereik moet word. Dit dui nie bloot op 'n toedrag van sake of toestand nie, aangesien sodanige differensiëring klaarblyklik nie met gelykheid as toestand gerym kan word nie.

\subsubsection{Verpligtinge van die staat met betrekking tot sosio-ekonomiese regte}

Daar word vervolgens oorbeweeg na 'n bespreking van die wyse waarop sosioekonomiese regte in die 1996 Grondwet verwoord word. Artikels 26 en 27, 25(5) en 29(1) is in hierdie verband ter sake.

(1) Artikels 26 en 27

Artikel 26(1) bepaal dat elkeen die reg op toegang tot geskikte behuising het, en ooreenkomstig artikel 27(1) het elkeen die reg op toegang tot gesondheidsorgdienste (wat reproduktiewe gesondheidsorg insluit), voldoende voedsel en water, en op sogenaamde "maatskaplike sekerheid", met inbegrip van maatskaplike bystand indien hulle nie in staat is om hulleself en hul afhanklikes te onderhou nie.

Die verpligting wat met betrekking tot die aangeleenthede in artikels 26(1) en 27(1) op die staat gelê word, blyk uit artikels 26(2) en 27(2). Dit is naamlik om redelike wetgewende en ander maatreëls te tref om binne die staat se beskikbare middele elk van hierdie regte in toenemende mate te verwesenlik. Uit hierdie formulering is dit duidelik dat daar nie gemeen word dat elk van hierdie regte onmiddellik sal realiseer nie. Sosioekonomiese aansprake word met ander woorde nie as regstreeks afdwingbare regte ingeklee nie. ${ }^{82}$ Die vermelding daarvan dat die staat verplig is om binne sy beskikbare middele elk van hierdie regte in toenemende mate te verwesenlik, laat blyk weer eens iets prosesmatigs. Alhoewel hierdie reg gekwalifiseer word in soverre die verwerkliking daarvan binne beskikbare middele moet geskied, hef hierdie beperking nie die staat se verpligting in hierdie verband op nie. Dit kan nie beskou word as regte wat in die

Du Plessis 1997 Stell LR 186. 
Grondwet ingeskryf is bloot omdat papier geduldig is en dit mooi of polities korrek klink nie. Omdat die staat 'n verpligting opgelê word wat in die toekoms toenemend verwesenlik moet word, is dit te betwyfel of 'n argument wat steun op 'n beperktheid van middele om werklik inhoud aan hierdie regte te gee, op die lang duur gehandhaaf sal kan word.

(2) Artikel 25(5)

Artikel 25(5) lê eweneens aan die staat 'n verpligting op om "redelike wetgewende en ander maatreëls [te] tref om binne sy beskikbare middele, toestande te skep wat burgers in staat stel om op 'n billike grondslag toegang tot grond te verkry." Terwyl dit onmiskenbaar is dat sosio-ekonomiese of rooi regte sterker figureer in die 1996 Grondwet as in die 1993 Grondwet, ${ }^{83}$ moet opgelet word dat die staat nie verplig word om iemand eiendom te laat toekom nie. Dit word wel verplig om bepaalde toestande te skep wat aan burgers op billike grondslag toegang tot grond kan gee. Ekonomiese oorwegings word ook eksplisiet as kwalifikasie vermeld.

(3) Artikel 29(1)

So ver dit onderwys aangaan word sekere verpligtinge aan die staat opgelê, soos blyk uit artikel 29(1):

29(1) Elkeen het die reg -

(a) op basiese onderwys, met inbegrip van basiese onderwys vir volwassenes; en

(b) op verdere onderwys, wat die staat, deur middel van redelike maatreëls, in toenemende mate beskikbaar en toeganklik moet maak. 
Alhoewel die staat se verpligting grootliks soos in artikels 26 en 27 hierbo geformuleer word, is die formulering in hierdie artikel uitgebrei om ook die toeganklikheid van onderwys in toenemende mate te bevorder.

Terwyl die onderskeid tussen sogenaamde blou en rooi regte soms gereduseer word tot 'n onderskeid tussen afdwingbare en onafdwingbare regte, ${ }^{84}$ kan gestel word dat hierdie tipering nie van toepassing is op die 1996 Grondwet nie. Dit blyk uit die feit dat die Konstitusionele Hof in sy eerste sertifiseringsuitspraak die argument dat sosioekonomiese regte nie beregbaar sou wees nie weens die begrotingsimplikasies wat dit mag inhou, afgewys het en hom bereid verklaar het om uitspraak oor sodanige sosioekonomiese aangeleenthede te gee. ${ }^{85}$ Hierdie bereidverklaring was in reaksie op betoë wat aan die Hof voorgelê is, wat aangevoer het dat sodanige sosiale regte onberegbaar is. Die belang van hierdie beslissing is dat so 'n benadering aan die howe 'n beslissingsreg in beleidsake gee. Kwessies van beleid is in die bedeling voor 1994 nie as 'n taak van die hof beskou nie, en howe was tradisioneel traag om hulle oor beleidsake uit te laat. In die nuwe bedeling sal die howe hul tradisionele terughoudendheid in hierdie verband moet laat vaar, iets wat reeds met wisselende mate van sukses gebeur.

Die voorsitter van die Menseregtekommissie, Barney Pityana, het hierdie selfde standpunt, naamlik dat sosio-ekonomiese regte afdwingbaar is, onlangs onderstreep en selfs die onderskeid tussen burgerlike en politieke regte aan die een kant en ekonomiese en sosiale regte aan die ander kant bevraagteken. Indien die grondwetlike stelsel nie sensitief is vir en antwoord op die sosio-ekonomiese aansprake van die armes en gemarginaliseerdes nie, sou dit volgens hom lei tot die legitimering van vervreemding, armoede en diskriminasie. ${ }^{86}$

84 Kyk bv Stern 1981 TSAR 244 met verwysing na die situasie by die aanvaarding van die Grundgesetz in Wes-Duitsland in 1949, waarin betreklik min sosio-ekonomiese regte annvanklik voorgekom het. Dit was nie omdat sodanige regte nie as belangrik beskou is nie, maar omdat daar besef is dat dit moeilik sou wees om enige praktiese werking daaraan te verleen, veral wanneer daar in die howe daarop 'n beroep gedoen sou moes word as subjektiewe regte.

85 In re: Certification of the Constitution of the Republic of South Africa 1996199610 BCLR 1289$1290(\mathrm{KH})$.

86 Ngqiyaza Business Day 5. 


\subsubsection{Horisontale werking}

'n Handves van Regte in 'n grondwet het sogenaamde horisontale werking indien dit nie net van toepassing is op die verhouding tussen staat en burger/onderdaan nie, maar ook 'n beslissende invloed uitoefen op verhoudings tussen individue, regspersone en niestaatlike samelewingsvorme.

Erkenning van horisontale werking bring uiteraard die privaatsfeer binne die invloedsveld van die publieke sfeer. Waar 'n liberale regstaat met sy klem op persoonlike vryheid sou wens om ingrype deur die staat op private aangeleenthede te beperk, sal 'n sosiale demokrasie die isolasie van die privaatsfeer teengaan en die privaatsfeer in die lig van die publieke sfeer beoordeel.

Alhoewel daar in akademiese en politieke kringe skerp meningsverskil hieroor bestaan het, is daar uiteindelik deur die Konstitusionele Hof beslis dat die 1993 Grondwet nie direkte horisontale werking het nie. ${ }^{87}$

In die 1996 Grondwet is daar egter 'n ingrypende koerswysiging in hierdie verband, soos blyk uit die formulering van sowel artikel 9(4) as artikel 2.

Artikel 9(3) gee uitdrukking aan die vertikale werking van die Grondwet wanneer bepaal word dat die staat nie regstreeks of onregstreeks onbillik teen iemand mag diskrimineer op grond van een of meer van 'n wye aantal gronde nie. Hierdie gronde sluit onder meer in: ras, geslagtelikheid, geslag, swangerskap, huwelikstaat, etniese of sosiale herkoms, kleur, seksuele georiënteerdheid, ouderdom, gestremdheid, godsdiens, gewete, oortuiging, kultuur, taal en geboorte. Artikel 9(4) maak dit duidelik dat fundamentele

87 Dit het onder meer geblyk uit Du Plessis and Others v De Klerk and Others 19963 SA 850 (KH) en die Gardener v Whitaker 19952 SA 672 (OK) en Gardener v Whitaker 19964 SA 337 (KH) gewysdes. Die teenoorstaande standpunt is egter in Mandela v Felati 19951 SA 251 (W) ingeneem waar beslis is dat politieke aktiwiteite nie alleen die verhouding tussen staat en burger raak nie, maar ook dié tussen burger en burger. 
regte ook horisontale werking het. Dit bepaal naamlik dat geen persoon regstreeks of onregstreeks onbillik teen iemand mag diskrimineer op een of meer van die gronde wat in subartikel (3) vermeld is nie. Daar kan aanvaar word dat die vermelding van "persoon" sowel natuurlike as regspersone insluit. ${ }^{88}$ Hierdie ontwikkeling word deur Du Plessis verwelkom as 'n verbetering op die 1993 Grondwet en as iets wat in ooreenstemming met internasionale tendense is. ${ }^{89}$

Artikel 2 van die 1996 Grondwet maak op sy beurt duidelik dat die Grondwet die hoogste reg van die Republiek is en dat enige regsvoorskrif of optrede wat daarmee onbestaanbaar is, ongeldig is. Wanneer artikel 2 met sy voorganger vergelyk word, naamlik met artikel 4(1) van die 1993 Grondwet, blyk dit dat daar 'n baie belangrike verskil daartussen is. Artikel 4(1) stel dat enige wet of handeling wat met die Grondwet onbestaanbaar is, nietig is in die mate waarin dit daarmee onbestaanbaar is. Dit is met ander woorde aansienlik enger geformuleer as artikel 2. Die groot verskil is daarin geleë dat die woord regsvoorskrif in die 1996 Grondwet ook die gemenereg en gewoontereg insluit, terwyl die woord wet van die 1993 Grondwet slegs op die statutereg betrekking gehad het. Die formulering in artikel 2 van die 1996 Grondwet is gevolglik van toepassing op veel meer as bloot die verhouding tussen die staat en die individu.

\subsubsection{Ontwikkeling van menslike potensiaal}

Die Aanhef tot die Grondwet vermeld spesifiek die doelwit van die ontwikkeling van die mens se potensiaal. Alhoewel ontwikkeling van mense tot hul volle potensiaal in meerdere denkrigtings figureer, moet opgelet word dat sodanige ontwikkelingsoogmerk veral sterk figureer in sosialistiese teorieë van geregtigheid. ${ }^{90}$

\section{Konklusie}

88 Kyk artikel 8(2): "'n Bepaling van die Handves van Regte bind 'n natuurlike of 'n regspersoon indien, en in die mate waarin, dit toepasbaar is met inagneming van die aard van die reg en die aard van enige plig deur die reg opgelê."

89 Kyk 1996 Stell LR 9 en die gesag in vn 21 aangehaal. 


\subsection{Die pole van regsekerheid en van buigsaamheid}

Daar is vroeër daarop gewys dat die onpresiese woordgebruik met betrekking tot die sogenaamde "waardegeoriënteerde terme" asook die interne dialektiek van belangrike waardes in die 1996 Grondwet probleme vir die vertolker daarvan kan skep. Terwyl daar enersyds geargumenteer kan word dat hierdie toedrag van sake nie regsekerheid bevorder nie, moet daar nogtans in gedagte gehou word dat regsekerheid nie die enigste deug in 'n regstelsel is nie. Aan die ander kant van die spektrum staan die deug van soepelheid en aanpasbaarheid. Terwyl laasgenoemde oorweging min of niks sal bydra tot die verheldering van die terminologiese probleem, mag dit interessante lig werp op die substantiewe probleem.

\subsection{Terminologies}

Teen die agtergrond van die beredenering hierbo kan die veelheid van waardes in die 1996 Grondwet nou weer in oënskou geneem word. By so 'n oorsig moet in gedagte gehou word dat die 1996 Grondwet reeds gesertifiseer en in werking gestel is. Daar kan met ander woorde aangeneem word dat hierdie dokument nie hersien gaan word om dit terminologies duideliker te kry nie. Alhoewel 'n poging tot sistematisering nie die Grondwet kan herskryf nie, mag dit 'n bydrae lewer tot helderder nadenke oor die waardeterme van die Grondwet. Groter duidelikheid mag ook nuttig wees vir insig in die substantiewe probleme met betrekking tot die dialektiek van grondwetlike waardes. In hierdie verband sal ook rekening gehou moet word met die toerusting of voorverstaan waarmee lesers die Grondwet benader.

Die volgende opmerkings kan bydra tot 'n vereenvoudiging van die groot aantal waardes wat in die Grondwet ingeskryf is. Dit wil voorkom of nie-rassigheid en nie-seksisme verskyningsvorme van gelykheid is. Gesien in die lig van die vermelding van die

90 Van Blerk Jurisprudence 142-143 met verwysing na die opvattings van Marx, CB Macpherson en 
bereiking van gelykheid in subartikel (a) is die afsonderlike vermelding daarvan binne

Suid-Afrikaanse konteks nie onvanpas of oortollig nie. Dit is duidelik dat benadeling op grond van geslagtelikheid nie naastenby dieselfde prominensie in die Suid-Afrikaanse regs- en politieke literatuur gekry het as dié met betrekking tot ras nie. ${ }^{91}$

\subsection{Voorstel}

Die bedeling wat deur die 1996 Grondwet in werking gestel is , kan na my mening soos volg getipeer word:

\section{Tipering}

Grondslag / Beginsel

Waardes

Sekondêre waarde

Maatstawwe vir staatsoptrede

Doelwitte
Grondwetlike demokrasie

Die oppergesag van die reg en die Grondwet

Menswaardigheid,

Gelykheid (waarby ingesluit is: nie-seksisme en nierassigheid)

Vryheid

Pluralisme $^{92}$

Openheid, onbevooroordeeldheid, onpartydigheid, regverdigbaarheid, redelikheid, verantwoordingspligtigheid, deursigtigheid en derglike meer.

Die bereiking van gelykheid

Die uitbouing van vryhede en menseregte

Die bewerkstelliging van maatskaplike geregtigheid

Die bewerkstelliging van 'n demokratiese

\section{Carol C Gould.}

91 Gouws 1993 Politikon 19.

92 Alhoewel hierdie waarde nie op die naam genoem word wanneer die kernwaardes van die 1996 Grondwet in die drie sleutelpassasies wat hierbo bespreek is nie, blyk dit wel 'n grondwetlike waarde te wees. Dit kan onder meer afgelei word uit die instelling van die Kommissie vir die Beskerming van die Regte van Kultuur-, Godsdiens- en Taalgemeenskappe in a 185. Die feit dat pluralisme nie eksplisiet in a 1(a) of a 7(1) vermeld word nie, dui daarop dat hierdie waarde nie dieselfde gewig dra as menswaardigheid, gelykheid en vryheid nie. Die waarde kan wel in die Aanhef ingelees word. Dit blyk uit die verwysing na die mense van Suid-Afrika as verenig in hul verskeidenheid. 


\begin{tabular}{|ll|}
\hline $\begin{array}{l}\text { Instandhoudings- } \\
\text { en bedryfsmeganismes }\end{array}$ & samelewing \\
& Algemene stemreg vir volwassenes \\
& 'n Nasionale gemeenskaplike kieserslys, gereelde \\
& verkiesings, 'n veelparty-stelsel van demokratiese \\
regering \\
Instansies wat waak oor & Howe \\
die beskerming en & Menseregtekommissie \\
bevordering van & Kommissie vir Geslagsgelykheid \\
grondwetlike waardes & Kommissie vir die Beskerming van die Regte van \\
& Kultuur-, Godsdiens- en Taalgemeenskappe ${ }^{95}$ \\
\hline
\end{tabular}

Die tipering van die Suid-Afrikaanse staat as 'n grondwetlike demokrasie veronderstel die oppergesag van die reg en erken die Grondwet as Grundnorm van die regstelsel. So 'n bedeling ken 'n besondere belangrike plek aan die regsprekende gesag toe en beperk die mag van die wetgewende en uitvoerende gesag. ${ }^{96}$ Die benaming "grondwetlike demokrasie" is wyd genoeg om die idee van regstaatlikheid in te sluit. Dit is ruim genoeg om ook erkenning te verleen aan elemente van sosiaalstaatlikheid, solank en in soverre hierdie elemente grondwetlik veranker is.

\section{4 'n Vrugbare dialektiek?}

Bogenoemde sistematisering met sy onderskeid tussen waardes en doelwitte los nie die dialektiek op so ver dit die spanning aangaan tussen die waardes van gelykheid en vryheid aan die een kant en die bereiking van gelykheid en die bevordering van vryhede en menseregte aan die ander kant nie. Vanweë hierdie spanning is dit nie moontlik om in abstracto 'n keuse daartussen uit te oefen nie. Alhoewel hierdie gebrek aan koherensie nie groter regsekerheid in die hand werk nie, kan geargumenteer word dat dit nie negatief beoordeel moet word so ver dit aanpasbaarheid en soepelheid aangaan nie. In hierdie 
verband moet in gedagte gehou word dat dit 'n verklaarde oogmerk van die 1996 Grondwet is om maatskaplike geregtigheid te bewerkstellig.

Die feit dat daar twee duidelike lyne in die Grondwet aangetoon kan word, een wat aansluit by die tipiese liberale regstaat, en 'n ander een wat in die teken van 'n sosiale demokrasie staan, het twee positiewe konsekwensies. In die eerste plek bind dit mense met verskillende staats- en samelewingsbeskouings in die nuwe bedeling in, omdat elk ten minste sekere belangrike beskouings waarmee hulle dit eens is, in die Grondwet ingeskryf sien. Dit is strategies belangrik vir die oorgangsfase vanaf 'n ou bedeling na 'n radikaal nuwe bedeling.

Die belangriker voordeel is egter dat dit aan regsprekers die geleentheid bied om in 'n bepaalde konteks met inagneming van alle relevante oorwegings 'n uitspraak te lewer. So kan nie net erkenning verleen word aan die oorhoofse strewe na groter maatskaplike geregtigheid nie, maar kan die spesifieke konteks en die individuele geval deeglik in berekening gebring word. Dat so 'n benadering regsekerheid op losser skroewe stel as wat verkieslik is, is 'n nadeel wat opgeweeg moet word teen die behoefte aan en noodsaak vir die bewerkstelliging van 'n regverdiger, werklik demokratiese samelewing.

\subsection{Die toekoms}

Of Suid-Afrika die weg van 'n liberale regstaat of van 'n sosiale demokrasie sal opgaan, sal die tyd uiteindelik leer. Die Grondwet self bied weens sy ingeboude dialektiek die moontlikhede en ruimte vir albei hierdie ontwikkelinge. ${ }^{97}$ Die howe gaan 'n belangrike rol in hierdie proses speel waar ' $n$ nuwe grondwetlike orde uit die verf van die teks na vore tree. Ook die wetgewende en uitvoerende gesag het 'n besliste rol hierin te speel.

96 Kyk Du Plessis en Corder Bill of Rights 20.

97 Du Plessis 1997 Stell LR 185-186 spreek die mening uit dat die feit dat menswaardigheid saam met vryheid en gelykheid as rigtinggewende waardemaatstaf in die 1996 Grondwet vermeld word 'n interessante moontlikheid skep om die dialektiese spanning tussen vryheid en gelykheid kreatief te hanteer en nie op die spits te dryf nie. 
Die moontlikheid kan nie uitgesluit word nie dat daar met die verloop van tyd 'n tipiese Suid-Afrikaanse regskultuur kan ontwikkel waarin uiteenlopende tradisies tot 'n nuwe eenheid saamgevoeg word, een waarin daar op gebalanseerde wyse 'n beskerming van sowel individuele as sosio-ekonomiese regte verleen sal word. ${ }^{98}$

As die aanvanklike wetgewing wat ingevolge die 1996 Grondwet aangeneem is, 'n aanduiding bied van die rigting wat die regstelsel as geheel gaan inslaan, wil dit voorkom of Suid-Afrika se grondwetlike demokrasie heelwat trekke van 'n sosiale demokrasie gaan vertoon. Die gemene reg en gewoontereg sal steeds hul invloed kenbaar maak, maar dan onder leiding van die waardes van die 1996 Grondwet, soos veral vervat in die Handves van Regte ${ }^{99}$

Of die beste strategie in die transformasie van die Suid-Afrikaanse regstelsel op weg na groter maatskaplike geregtigheid sal wees om uit liefde vir die tradisie dit wat goed daarin is te koester en uit te bou en of daar eerder afgebreek en oorgebou sal moet word, is 'n vraag wat tans aan die orde gestel word. Dit stel besluitnemers en in besonder die regsgemeenskap voor 'n bepaalde keuse. Dat hierdie keuse 'n groot impak kan hê op die wyse waarop die private sfeer in die toekoms gehanteer sal word, is duidelik. Die probleem met betrekking tot die dialektiek van waardes in die 1996 Grondwet is 'n probleem wat tans met die uitsprake van die Konstitusionele Hof in die proses van beantwoording is.

\subsection{Toekomstige navorsing}

Verdere navorsing word in die vooruitsig gestel om in te gaan op die moontlikheid van 'n juridiese versoeningsmodel wat die sosiaal-demokratiese en die regstaatlike lyne in die Grondwet kan saambind. So-iets sou egter slegs moontlik wees indien die dialektiek wat hierbo bespreek is, nie in ideologiese sin opgeneem word nie. Hierdie lyne sal

98 Die ontwikkeling van so 'n tipies Suid-Afrikaanse menseregtekultuur is reeds deur Du Plessis en Corder Bill of Rights 35 in die vooruitsig gestel in hul bespreking van Hoofstuk 3 van die 1993 Grondwet. 
geïntegreer moet word as take van die staat binne 'n breër geregtigheidsraamwerk. Regsvergelykende navorsing (met toespitsing op veral die Duitse reg) kan heel waarskynlik van groot nut wees op hierdie terrein.

99 Kyk a 39(2). 


\section{BIBLIOGRAFIE}

\section{Boeke}

Davis D "Equality and Equal Protection" in Van Wyk D, Dugard J, De Villiers B en Davis D (reds) Rights and Constitutionalism The new South African Legal Order (Juta Kenwyn 1994) 196-211

Davis D, Chaskalson M, De Waal J "Democracy and Constitutionalism: The Role of Constitutional Interpretation" in Van Wyk D, Dugard J, De Villiers B en Davis D (reds) Rights and Constitutionalism The new South African Legal Order (Juta Kenwyn 1994) 1-130

Dugard J "International Human Rights" in Van Wyk D, Dugard J, De Villiers B en Davis D (reds) Rights and Constitutionalism The new South African Legal Order (Juta Kenwyn 1994) 171-195

Du Plessis en Corder Bill of Rights

Du Plessis LM en Corder H Understanding South Africa's Transitional Bill of Rights (Juta Kenwyn 1994)

Ferreira Staatsregtelike Onregmatigheid

Ferreira GM Staatsregtelike Onregmatigheid LLD-proefskrif PU vir CHO (Potchefstroom 1995)

Peaslee Constitutions

Peaslee AJ Constitutions of Nations Vol IV The Americas (Nijhoff Den Haag 1970)

Gamble Introduction 
Gamble A An Introduction to Modern Social and Political Thought (St Martin's Press New York 1981)

\section{Jolowicz Lectures}

Jolowicz HF Lectures on Jurisprudence (onder redaksie van JA Jolwicz) (University of London Londen 1963)

Sabine Political Thought

Sabine GH en Thorson TL An Intoduction to Modern Social and Polititical Thought (Harcourt Brace College Publishers Fort Worth 1989)

Simpson Invitation

Simpson AWB An Invitation to Law (Blackwell Oxford 1994)

Van Blerk Jurisprudence

Van Blerk AE Jurisprudence An Introduction (Butterworths Durban 1996)

Van Haersolte RAV "John Rawls" in Cliteur PB en Loth MA (reds) Rechtsfilosofen van de twintigste eeu (Gouda Quint Arnhem 1992) 209-228

Van Eikema Hommes Trends

Van Eikema Hommes HJ Major Trends in the History of Legal Philosophy (NorthHolland Publishing Company Amsterdam 1979)

Van Eikema Hommes Elementaire Grondbegrippen Van Eikema Hommes HJ De Elementaire Grondbegrippen der Rechtswetenschap Een Juridische Methodologie 2de druk (Kluwer Deventer 1983)

Van Niekerk P "Regering en Staatsgesag: die Staat, die Reg en die Politiek" in Wiechers M en Bredenkamp F (reds) Die Staat: Teorie en Praktyk (Van Schaik Pretoria 1996) $139-162$ 
Van Wyk D "Introduction to the South African Constitution" in Van Wyk D, Dugard J, De Villiers B en Davis D (reds) Rights and Constitutionalism The new South African Legal Order (Juta Kenwyn 1994) 131-170

\section{Tydskrifartikels}

Botha H "The values and principles underlying the 1993 Constitution" 1994 SAPR/PL 233-244

Carpenter G "The Republic of South Africa Constituion Act 200 of 1993 - an overview" 1994 SAPR/PL 222-232

Carpenter G "Fundamental Rights- Is there a pecking order?" Codicillus 27-32

Chaplin J "Subsidiarity and Sphere Sovereignty: Catholic and Reformed Conceptions of the Role of the State" 1995 Orientation 104-129.

Cliteur PB "Rechtsbeginselen: Tussen Natuurrecht en Rechtspositivisme" 1987 Philosophia Reformata 57-70

De Wet E "Can the social state principle in Germany guide state action in South Africa in the field of social and economic rights?" 1995 SAJHR 30-49

Du Plessis LM "The genesis of the chapter on fundamental rights in South Africa's transitional constitution" 1994 SAPR/PL 1-21

Du Plessis LM "The Bill of Rights in the Working Draft of the New Constitution: an Evaluation of Aspects of a Constitutional Text Sui Generis" Stellebosch Law Review 1996 3-24 
Du Plessis LM "The jurisprudence of interpretation and the exigencies of a new constitutional order in South Africa" Voordrag gelewer by 'n Regsteoriekonferensie Doing things with words -- On meaning in legal interpretation wat gehou is by die Randse Afrikaanse Universiteit, 1-3 September, 1997.

Du Plessis LM "Menseregte in die Skadu’s en Skanse van die Ivoortoring ('n Akademiese waardering van enkele fasette van menseregtebeskerming in Suid-Afrika se finale Grondwet)" 1997 Stell LR 181-191

De Waal "A Comparative Analysis of the Provisions of German Origin in the Interim Bill of Rights" 1995 SAJHR 1-29

Erasmus G en De Waal J "Die Finale Grondwet Legitimiteit en Ontstaan" 1997 Stellenbosse Regstydskrif 31

Gouws A "Women in Political Science: (An)other Look at the Discipline” 1993 Politikon $5-24$

Gouws A "Women, civil society and citizenship: a reaction to Schreiner" in Rhoodie N en Liebeberg I (reds) Democratic Nation-building in South Africa 1994 315-324

Gutto S "Concepts, Principles or Rules: the Meaning of Constitutionalised Rights in the Context of International Law" Voordrag gelewer by 'n Regsteoriekonferensie Doing things with words -- On meaning in legal interpretation wat gehou is by die Randse Afrikaanse Universiteit, 1-3 September 1997.

Hiemstra VG "Suid-Afrika terug in die wêreld langs die weg van die regstaatbeginsel" 1985 TSAR 1-10

Michelman FI "Constitutional authorship and the unoriginalist mode of constitutional interpretation" Voordrag gelewer by 'n Regsteoriekonferensie Doing things with words -- 
On meaning in legal interpretation wat gehou is by die Randse Afrikaanse Universiteit, 1-3 September 1997.

Mureinik E "A Bridge to Where? Introducing the Interim Bill of Rights" 1994 SAJHR $31-48$

Ngqiyaza B "Socioeconomic rights must be enforced in SA - Pityana" Business Day 19 September 19974

Stern K "A society based on the rule of law and social justice: constitutional model of the Federal Republic of Germany" 1981 TSAR 241-250

Van der Merwe D "The Roman-Dutch Law: From Virtual Reality to Constitutional Resource" Voordrag gelewer by 'n Regsteoriekonferensie Doing things with words -- On meaning in legal interpretation wat gehou is by die Randse Afrikaanse Universiteit, 1-3 September 1997.

Hommes HJ Van Eikema "De materiële rechtsstaatsidee" 1978 TSAR 42-52

Van Wyk DH "Suid-Afrika en die regstaatidee" 1980 TSAR 152-167

Van Wyk D "The South African Bill of Rights: an evaluation" 1994 SAPR/PL 278-286

Venter F "Milestones in the evolution of the new South African Constitution and some of its salient features" 1994 SAPR/PL 211-232

Venter F "Constitution-making and the Legitimacy of the Constitution" Voordrag gelewer by die IACL Round Table Conference, Turku, 23-24 May 1997

Venter F "Die Betekenis van die Bepalings van die Grondwet Die Aanhef en Hoofstuk 1" 1998 PER 1-64 
Venter JJ "Reformational University Basis in Operation" 1994 Orientation 260-295

\section{Regspraak}

Du Plessis and Others $v$ De Klerk and Another 19963 SA 850 (KH)

Gardener v Whitaker 19952 SA 672 (OK)

Gardener $v$ Whitaker 19964 SA 337 (KH)

Ex Parte Chairperson of the Constitutional Assembly: in re Certification of the Constitution of the Republic of South Africa 1996199610 BCLR 1253 (KH)

Mandela v Felati 19951 SA 251 (W)

Qozeleni v Minister of Law and Order 19943 SA 625 (OK)

$S$ v Makwanyane 1995 (6) BCLR $665(\mathrm{KH})$

$S v$ Zuma and Others 1995(4) BCLR $401(\mathrm{KH})$ 